\title{
PERBANDINGAN DATA ANTROPOMETRI BERDASARKAN SUKU DI INDONESIA
}

\author{
Sri Zetlii ${ }^{*}$, Nofriani Fajrah², Melanda Paramita ${ }^{3}$ \\ ${ }^{1,2,3}$ Program Studi Teknik Industri, Universitas Putera Batam \\ Jl. Letjend. R. Soeprapto, Tembesi, Batam, Kepulauan Riau \\ *e-mail: zetli.sri@gmail.com
}

\begin{abstract}
Anthropometry is defined as the science of measurement and art in applying human physical properties, which is one of the most important factors to consider in designing a product. Products that meet ergonomic rules are products that are designed according to the dimensions of the user's body. Various factors affect anthropometric data, one of which is ethnicity. Ethnicity is defined as a group of people identified through ancestral heritage, certain languages and certain cultures. Indonesia has more than 300 different ethnic groups, so it is important to represent anthropometric data based on ethnicity. Batam City has a heterogeneous community consisting of various tribes and groups. The dominant tribes include Batak, Javanese, Malay, Minang and Chinese. With the variation in anthropometric size, it is not possible for a design system to adjust to all types of sizes, therefore there is a need for a database of anthropometric sizes in Indonesia. From the comparative test conducted by Anova testing, all 36 anthropometric with Sig. $<\alpha(0.05)$ which means that there are differences in Anthropometric between the five terms. Whereas for differences in Anthropometric Batak and Javanese are 19 same and 17 different, Batak and Malay are 14 same and 22 different, Batak and Minang are 12 same and 24 different, Batak and Chinese are 14 same and 22 different, Java and Malay are 12 same and 24 different, Java and Minang are 12 same and 24 different, Java and Chinese are 12 same and 24 different, Malay and Minang are 9 same and 27 different, Malay and Chinese are 14 same and 22 different, Minang and Chinese are 14 same and 22 different. The results of anthropometry obtained based on this research are expected to be a recommendation in the development of more ergonomic tools for users, especially the people of Indonesia.
\end{abstract}

Keywords : Anthropometry, Statis, Ethnicity

\section{Pendahuluan}

Antropometri didefinisikan sebagai ilmu pengukuran dan seni dalam mengaplikasikan sifat fisik manusia (Kroemer \& Grandjean, 2005), yang merupakan salah satu faktor terpenting untuk dipertimbangkan dalam mendesain suatu produk. Produk yang memenuhi kaidah ergonomi adalah produk yang dirancangan sesuai dengan dimensi tubuh penggunanya. Dengan demikian, ia dapat menggunakan produk tersebut secara efektif, aman, sehat, nyaman, dan efisien (Sutalaksana \& Iftikar, 2006). Selain itu produk yang didesain sesuai dengan antropometri manusia dapat meningkatkan performansi dan produktifitas kerja, serta mengurangi frekuensi kecelakaan kerja (Jaruwan Klamklay, Yodpijitb, \& Pattersonc, 2008).

Berbagai macam faktor yang mempengaruhi data antropometri seperti, etnis, jenis kelamin, umur, pekerjaan, jenis pakaian, dan cacat fisik (Eko Nurmianto, 2005). Etnis didefinisikan sebagai suatu kelompok orang yang teridentifikasi melalui warisan leluhur, bahasa tertentu dan kebudayaan tertentu. Perbedaan etnis pada data antropometri sudah diteliti dari bertahun-tahun yang lalu. Seperti penelitian yang dilakukan oleh (Yap, Chan, Chan, \& Wang, 2001) yang meneliti mengenai perbedaan panjang bagian atas tubuh orang dewasa di China, Malaysia, dan India, kemudian (Ball et al., 2010) menemukan signifikansi variasi antara bentuk kepala etnis China dengan kaum Kaukasian. Tidak hanya itu, perbedaan data antropometri tidak hanya ditemui pada negara yang berbeda, tetapi variasi etnis pada suatu negara bisa juga menjadi penyebab. Contohnya penelitian yang dilakukan oleh (Yokota, 2005) yang menemukan perbedaan pada antropometri wajah dan bentuk kepala antara pria kulit hitam dan putih di Amerika, contoh lainnya adalah (Jahanshahi, Golalipour, \& Haidari, 2008) yang menemukan perbedaan antropometri pada bagian wajah pada berbagai macam etnis di Iran. 
Maka dari itu dalam menyesuaikan suatu alat atau fasilitas pada suatu populasi atau etnis tertentu sangatlah krusial dalam pemilihan data antropometrinya.

Indonesia adalah negara kepulauan yang memiliki total 17.508 pulau dengan lima pulau besar yaitu Sumatera, Kalimantan, Sulawesi, Jawa, dan Papua. Penduduk yang tinggal pada pulau tersebut terdiri dari berbagai macam suku. Indonesia mempunyai lebih dari 300 kelompok suku yang berbeda, perbedaan suku ini menimbulkan pertanyaan apakah ada perbedaan data antropometri pada suku yang berbeda pula. Seperti yang sudah diungkapkan oleh Abeysekera dan Shahnavaz, bahwa berbeda populasi berbeda pula antropometrinya, tidak menutup kemungkinan bahwa perbedaan antropometri juga terjadi pada suku yang berbeda pula walaupun berasal dari satu Negara (D.A. \& Shahnavaz, 1989).

Dengan mempertimbangkan bahwa Indonesia terdiri dari ratusan kelompok suku, maka dari itu sangat penting merepresentasikan data antropometri berdasarkan suku. Bagaimanapun juga, penelitian mengenai antropometri yang sudah dilakukan terbatas mengenai kemungkinan perbedaan suku di Indonesia (Tan Kay Chuan, Hartono, \& Kumar, 2010). Data antropometri untuk Indonesia yang dimiliki Menteri Ketenagakerjaan Indonesia adalah pada tahun 1955 (Soetisna, Mahachandra, \& Widyanti, 2014), data tersebut perlu diperbaharui karena untuk mengetahui perkembangan antropometri populasi di Indonesia. Penelitian mengenai data antropometri orang Indonesia yang dilakukan oleh Nurmianto (2004) hanya melakukan interpolasi dari orang Inggris dan Hongkong. Data yang sudah ada ini tidak menjelaskan secara mendalam mengenai variasi suku-suku yang ada di Indonesia. Sedangkan penelian yang dilakukan oleh (Esmika, 2015) hanya meneliti data antropometri tangan pada 3 (tiga) suku yang ada di Indonesia yaitu Jawa, Sunda dan Batak. Hasil penelitian didapat bahwa terdapat beberapa dimensi tubuh yang berbeda dari ke tiga suku seperti dimensi panjang tangan orang Jawa paling besar dibandingkan dua suku lainnya, sedangkan orang Batak memiliki dimensi tangan yang lebih lebar dan tebal dari suku Jawa dan Sunda. Penelitian juga dilakukan oleh (Fauzan, Manela, \& Hidayat, 2019) yaitu membandingkan indeks cephalic (bentuk kepala manusia) suku Minang dan suku Jawa, dimana terdapat perbedaan yang signifikan diantara kedua suku tersebut.

Maka, sangatlah menarik untuk mengetahui apakah ada perbedaan signifikan pada data antropometri pada suku-suku lainnya di Indonesia. Kota Batam merupakan sebuah kota terbesar di Provinsi Kepulauan Riau, Indonesia. Menurut
Dinas Kependudukan dan Catatan Sipil Kota Batam per 2015, jumlah penduduk Batam mencapai 1.037.187 jiwa. Masyarakat Kota Batam merupakan masyarakat heterogen yang terdiri dari beragam suku dan golongan. Suku yang dominan antara lain Melayu, Jawa, Batak, Minangkabau, dan Tionghoa. Dalam situs Wikipedia disebutkan bahwa walaupun suku (etnis) Tionghoa bukan merupakan suku asli Indonesai tetapi setelah negara Indonesia merdeka, orang Tionghoa yang berkewarganegaraan Indonesia digolongkan sebagai salah satu suku dalam lingkup nasional Indonesia, sesuai Pasal 2 UU Nomor 12 Tahun 2006 tentang Kewarganegaraan Republik Indonesia. Dalam sensus penduduk pada tahun 2000, ketika untuk pertama kalinya responden sensus ditanyai mengenai asal etnis mereka, hanya $1 \%$ atau 1.739.000 jiwa yang mengaku sebagai Tionghoa. Perkiraan kasar yang dipercaya mengenai jumlah suku Tionghoa-Indonesia saat ini ialah berada di antara kisaran 4\% - 5\% dari seluruh jumlah populasi Indonesia. Sehingga data antropometri suku Tionghoa juga mesti dipertimbangkan dalam perancangan produk yang di khususkan untuk orang Indonesia. Selain itu pengetahuan mengenai persamaan atau perbedaan suku pada data antropometri di Indonesia akan mempengaruhi perkembangan database antropometri Indonesia. Adanya variasi ukuran antropometri tidak memungkinkan untuk suatu sistem desain menyesuaikan semua jenis ukuran, maka dari itu perlu adanya semacam database mengenai ukuran antropometri di Indonesia. Data antropometri sangat berguna untuk membuat desain yang efektif untuk meningkatkan performansi dan produktivitas (Jaruwan Klamklay et al., 2008).

Pengukuran antropometri manusia dibedakan dalam 2 jenis yaitu dimensi statis dan dinamis/fungsional (Sanders dan McCormick, 1993). Dimensi statis adalah pengukuran yang dilaksanakan pada saat tubuh manusia dalam sikap statis (posisi diam di tempat. Dimensi dinamis adalah pengukuran yang dilaksanakan pada saat tubuh manusia menggerakkan badannya pada sikap-sikap posisi kerja tertentu. Walaupun ukuran-ukuran dimensi fungsional lebih berarti untuk aktivitas manusia sesungguhnya, karena sulit cara pengukurannya, maka saat ini lebih banyak digunakan data-data antropometri statis dibandingkan dengan data-data antropometri dinamis.

Sehingga tujuan dari penelitian ini adalah untuk membandingkan data antropometri statis berdasarkan suku di Indonesia, yaitu suku Batak, Jawa, Melayu, Minang dan Tionghoa. Hasil dari antropometri yang diperoleh berdasarkan penelitian ini diharapkan dapat dimasukan kedalam database Antropometri Indonesia dan 
juga dapat menjadi rekomendasi dalam pengembangan alat yang lebih ergonomis bagi pengguna khususnya masyarakat Indonesia.

\section{Landasan Teori}

\subsection{Defenisi Antropometri}

Antropomteri berasal dari bahasa Yunani yaitu anthropos yang berarti manusia dan metron yang berarti pengukuran (Bridger, 1995). Menurut (Kroemer \& Grandjean, 2005) data antropometri digunakan untuk menentukan dimensi dari tempat kerja, peralatan, furnituredan pakaian, sehingga dapat memenuhi kebutuhan manusia dan untuk meyakinkan bahwa ketidaksesuaian antara dimensi peralatan atau produk dengan dimensi pengguna dapat dihindarkan.

Data antropometri sangat penting dalam menentukan alat dan cara mengopersikannya. Kesesuaian hubungan antara antropometri pekerja dengan alat yang digunakan sangat berpengaruh pada sikap kerja, tingkat kelelahan, kemampuan kerja dan produktivitas kerja (Tarwaka, 2015).

\subsection{Tipe Data Antropometri}

Dalam aplikasinya, tipe antropometri terbagi atas dua bagian:

1. Dimensi Tubuh Struktural (Antropometri Statis)

Pengukuran dimensi tubuh manusia pada posisi diam dan linear pada permukaan tubuh. Ada beberapa faktor yang mempengaruhi ukuran tubuh manusia, sehingga sudah semestinya seorang perancang produk harus memperhatikan faktor-faktor tersebut yang antara lain adalah Umur, Jenis kelamin (sex), Suku atau bangsa (ethnic), dan Posisi tubuh (posture).

2. Dimensi Tubuh Fungsional (Antropometri Dinamis)

Pengukuran keadaan dan ciri-ciri fisik manusia dalam keadaan bergerak atau memperhatikan gerakan-gerakan yang mungkin terjadi saat pekerja tersebut melakukan kegiatannya.

\subsection{Pengukuran Data Antropometri}

Adapun anggota tubuh yang perlu diukur adalah seperti terlihat pada gambar 1 sebagai berikut (S. Wignjosoebroto, 2003):

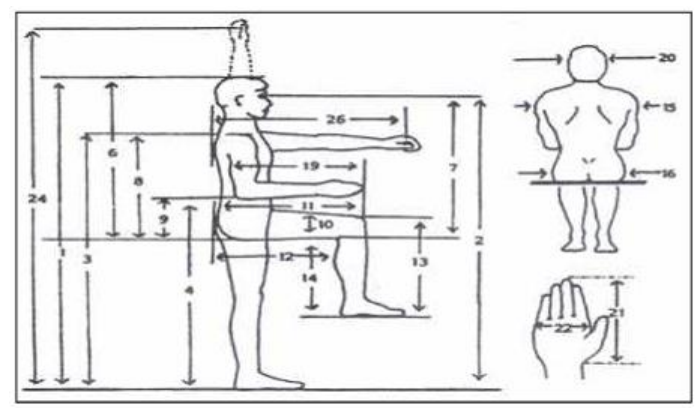

Gambar 1. Pengukuran Data Antropometri

\section{Metodologi Penelitian}

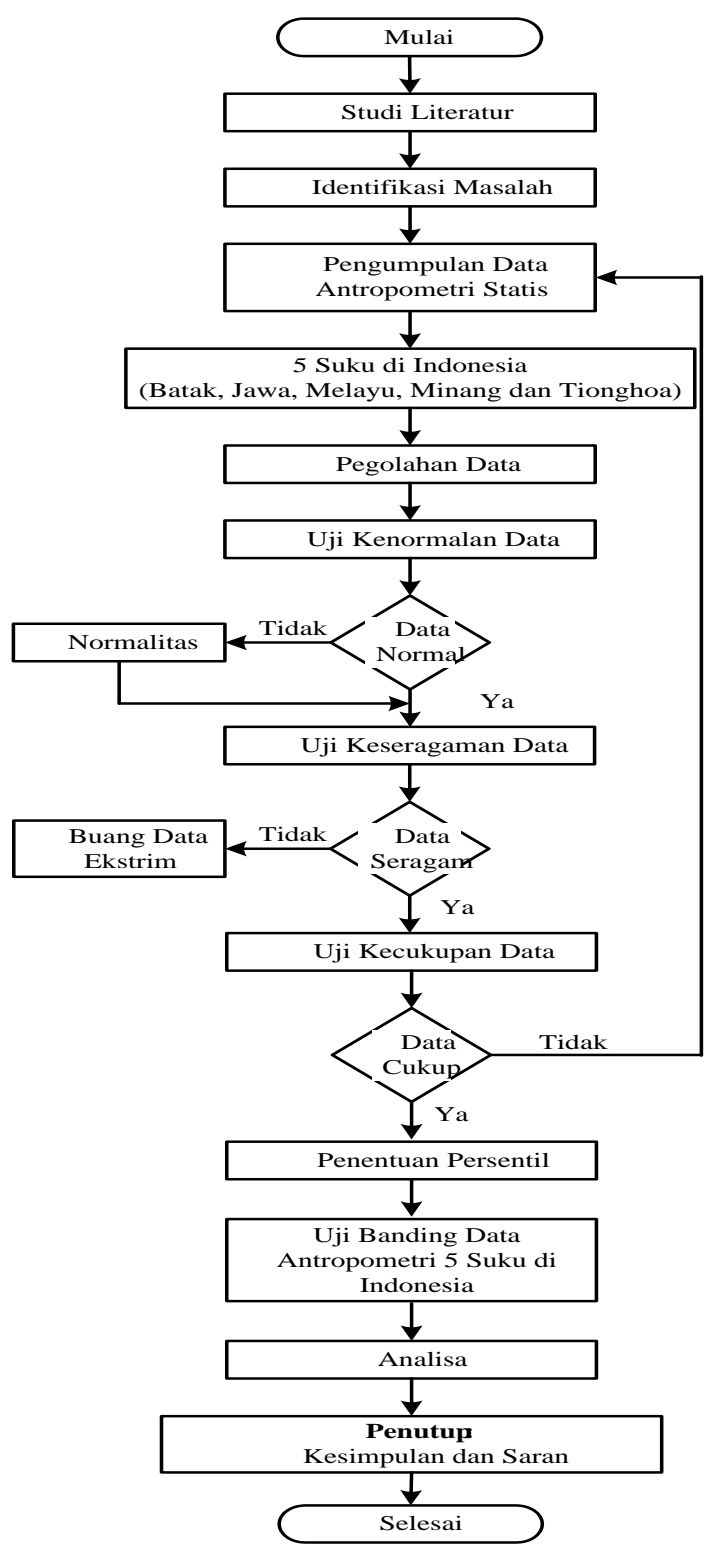

Gambar 2. Desain Penelitian

\subsection{Variabel Penelitian}

Pengukuran dilakukan terhadap 36 dimensi tubuh antropometri statis yang terlihat pada tabel 1.

\subsection{Populasi dan Sampel}

Populasi pada penelitian ini adalah semua yang bersuku Batak, Jawa, Melayu, Minang dan Tionghoa di Kota Batam. Sedangkan sampel dalam penelitian adalah sebagian atau wakil populasi yang diteliti. Dalam penelitian ini yang dijadikan sampel sebanyak 100 mahasiswa dari masing-masing suku Batak, Jawa, Melayu, Minang dan Tionghoa di Kota Batam dengan 
menggunakan Simple Random Sampling sebagai teknik pengumpulan sampel. Adapun kriteria dari data yang akan dijadikan sampel adalah jenis kelamin laki-laki ataupun perempuan, usia 17 sampai 27 tahun dengan asumsi pertumbuhan tubuh mereka sudah maksimal, berdomisili di Kota Batam, generasi di atas responden (orangtua) merupakan kelompok suku yang sama, tidak cacat fisik dan untuk sampel wanita tidak dalam keadaan hamil.

Tabel 1. Jenis Pengukuran Antropometri

\begin{tabular}{|c|c|c|c|c|c|}
\hline No & Data Antropometri & Kode & No & Data Antropometri & Kode \\
\hline 1 & Tinggi Tubuh & D1 & 19 & Lebar Pinggul & D19 \\
\hline 2 & Tinggi Mata & D2 & 20 & Tebal Dada & D20 \\
\hline 3 & Tinggi Bahu & D3 & 21 & Tebal Perut & D21 \\
\hline 4 & Tinggi Siku & D4 & 22 & Panjang Lengan Atas & D22 \\
\hline 5 & Tinggi Pinggul & D5 & 23 & Panjang Lengan Bawah & D23 \\
\hline 6 & Tinggi Tulang Ruas & D6 & 24 & $\begin{array}{l}\text { Panjang Rentang Tangan Ke } \\
\text { Depan }\end{array}$ & D24 \\
\hline 7 & Tinggi Ujung Jari & D7 & 25 & $\begin{array}{l}\text { Panjang Bahu-Genggaman } \\
\text { Tangan Ke Depan }\end{array}$ & D25 \\
\hline 8 & $\begin{array}{l}\text { Tinggi Dalam Posisi } \\
\text { Duduk }\end{array}$ & D8 & 26 & Panjang Kepala & D26 \\
\hline 9 & $\begin{array}{l}\text { Tinggi Mata Dalam Posisi } \\
\text { Duduk }\end{array}$ & D9 & 27 & Lebar Kepala & D27 \\
\hline 10 & $\begin{array}{l}\text { Tinggi Bahu Dalam Posisi } \\
\text { Duduk }\end{array}$ & D10 & 28 & Panjang Tangan & D28 \\
\hline 11 & $\begin{array}{l}\text { Tinggi Siku Dalam Posisi } \\
\text { Duduk }\end{array}$ & D11 & 29 & Lebar Tangan & D29 \\
\hline 12 & Tebal Paha & D12 & 30 & Panjang Kaki & D30 \\
\hline 13 & Panjang Lutut & D13 & 31 & Lebar Kaki & D31 \\
\hline 14 & Panjang Popliteal & D14 & 32 & $\begin{array}{l}\text { Panjang Rentangan Tangan Ke } \\
\text { Samping }\end{array}$ & D32 \\
\hline 15 & Tinggi Lutut & D15 & 33 & Panjang Rentangan Siku & D33 \\
\hline 16 & Tinggi Popliteal & D16 & 34 & $\begin{array}{l}\text { Tinggi Genggaman Tangan Ke } \\
\text { Atas Dalam Posisi Berdiri }\end{array}$ & D34 \\
\hline 17 & Lebar Sisi Bahu & D17 & 35 & $\begin{array}{l}\text { Tinggi Genggaman Ke Atas } \\
\text { Dalam Posisi Duduk }\end{array}$ & D35 \\
\hline 18 & Lebar Bahu Bagian Atas & D18 & 36 & Panjang Genggaman Tangan & D36 \\
\hline
\end{tabular}

\subsection{Pengolahan Data}

Setelah data-data yang dibutuhkan terkumpul, maka dilakukan pengolahan data sebagai berikut:

1. Uji Keseragaman Data

Data dikatakan seragam apabila data tersebut berada pada Batas Kontrol Atas (BKA) dan Batas Kontrol Bawah (BKB), sebaliknya data dikatakan tidak seragam apabila data tersebut berada diluar Batas Kontrol Atas (BKA) dan Batas Kontrol Bawah (BKB).

$$
\begin{array}{ll}
\mathrm{BKA} & =\bar{X}+3 \sigma \mathrm{x} \\
\mathrm{BKB} & =\bar{X}-3 \sigma \mathrm{x}
\end{array}
$$

Rumus 1. Rumus BKA dan BKB

$$
\sigma \mathrm{X}=\sqrt{\frac{n \sum X i^{2}-\left(\sum X i\right)^{2}}{n(n-1)}}
$$

Rumus 2. Rumus Standar Deviasi

$$
\bar{X} \quad=\frac{\sum X i}{n}
$$

Rumus 3. Rumus Rata-Rata

$$
\text { Dimana: }
$$

$$
\begin{aligned}
& \mathrm{Xi}=\text { Nilai } \mathrm{x} \text { ke- } \mathrm{i} \\
& \bar{X}=\text { nilai rata-rata } \\
& \sigma \mathrm{x}=\text { nilai standar deviasi } \\
& \mathrm{n}=\text { banyaknya data }
\end{aligned}
$$

2. Uji Kenormalan Data

Uji kenormalan data bertujuan untuk menentukan data tersebut berdistibusi normal atau tidak yaitu dengan membandingkan chisquare dengan chi-table menggunakan software SPSS for Windows 12.0.

3. Uji Kecukupan Data

Jika nilai $N^{\prime}>N$, berarti data yang dikumpulkan belum cukup mewakili populsi sehingga dibutuhkan penambahan data sampai dihasilkan N > N'. Uji Kecukupan Data dapat dilakukan dengan menggunakan persamaan:

$$
\mathrm{N}^{\prime}=\left[\frac{k / s \sqrt{n \sum X i^{2}-\left(\sum X i^{2}\right)}}{\sum X i}\right]^{2}
$$

Rumus 4. Rumus Uji Kecukupan Data

4. Perhitungan Persentil

Tabel 2. Rumus Persentil

\begin{tabular}{cc}
\hline Persentil & Perhitungan \\
\hline $1^{\text {th }}$ & $\dot{x}-2.325 \mathrm{SD}$ \\
$2.5^{\text {th }}$ & $\dot{x}-1.96 \mathrm{SD}$ \\
$5^{\text {th }}$ & $\dot{x}-1.645 \mathrm{SD}$ \\
$10^{\text {th }}$ & $\dot{x}-1.28 \mathrm{SD}$ \\
$50^{\text {th }}$ & $\dot{x}$ \\
$90^{\text {th }}$ & $\dot{x}+1.28 \mathrm{SD}$ \\
$95^{\text {th }}$ & $\dot{x}+1.645 \mathrm{SD}$ \\
$97.5^{\text {th }}$ & $\dot{x}+1.96 \mathrm{SD}$ \\
$99^{\text {th }}$ & $\dot{x}+2.325 \mathrm{SD}$ \\
\hline
\end{tabular}

$$
\text { Dimana: }
$$

$$
\begin{aligned}
& \bar{X}=\text { nilai rata-rata } \\
& \mathrm{SD}=\text { Standar Deviasi }
\end{aligned}
$$

\subsection{Analisis Data}

1. Analisa Unvariat

Analisa unvariat dimaksudkan untuk melihat gambaran distribusi frekwensi masing-masing variabel yang diteliti, yaitu 36 dimensi tubuh antropometri statis pada suku Melayu, Jawa, Batak, Minang dan Tionghoa.

2. Analisa Bivariat

Analisis bivariate digunakan untuk mencari perbedaan antara ke lima variable penelitian yaitu Suku Batak, Suku Jawa, Suku Melayu, Suku Minang dan Suku Tionghoa. Uji statistik yang digunakan untuk mengetahui perbedaan antara kelima suku ini adalah uji Anova Satu Jalur. Analisis data penelitian ini diolah dengan program SPSS versi 17 (M. Sopiyudin D., 2012) dalam (Prabawati, 2012). Dalam pengujian terdapat terdapat dua jenis hipotesa yaitu:

Ha. Adanya perbedaan data antropometri antara kelima suku.

Ho. Tidak terdapatnya perbedaan data antropometri antara kelima suku.

Interpetasi hasil dari pengujian adalah sebagai berikut:

1. Jika $\mathrm{p} \leq 0,05$ maka Ho ditolak. 
2. Jika $\mathrm{p}>0,05$, maka Ho diterima.

\section{Hasil Penelitian dan Pembahasan}

4.1. Hasil Penelitian

4.1.1 Data Responden Suku Batak

Tabel 3. Umur Responden Suku Batak

\begin{tabular}{crrrrr}
\hline \multirow{2}{*}{ Umur } & $\begin{array}{c}\text { Freq- } \\
\text { uensy }\end{array}$ & Percent & $\begin{array}{c}\text { Valid } \\
\text { Percent }\end{array}$ & $\begin{array}{c}\text { Cumul- } \\
\text { ative }\end{array}$ \\
\hline Valid & 18 & 2 & 2 & 2 & 2 \\
& 19 & 11 & 11 & 11 & 13 \\
20 & 14 & 14 & 14 & 27 \\
21 & 16 & 16 & 16 & 43 \\
22 & 13 & 13 & 13 & 56 \\
23 & 17 & 17 & 17 & 73 \\
24 & 10 & 10 & 10 & 83 \\
25 & 9 & 9 & 9 & 92 \\
26 & 7 & 7 & 7 & 99 \\
27 & 1 & 1 & 1 & 100 \\
Total & 100 & 100 & 100 & \\
\hline
\end{tabular}

Tabel 4. Jenis Kelamin Responden Suku Batak

\begin{tabular}{llrrrr}
\hline Jenis Kelamin & $\begin{array}{c}\text { Frequ } \\
\text { ency }\end{array}$ & Percent & $\begin{array}{c}\text { Valid } \\
\text { Percent }\end{array}$ & $\begin{array}{c}\text { Cumulative } \\
\text { Percent }\end{array}$ \\
\hline \multirow{4}{*}{ Valid } & Laki-Laki & 87 & 87 & 87 & 87 \\
\cline { 2 - 6 } & Perempuan & 13 & 13 & 13 & 100 \\
& Total & 100 & 100 & 100 & \\
\hline
\end{tabular}

4.1.2 Data Responden Suku Jawa

Tabel 5. Umur Responden Suku Jawa

\begin{tabular}{lrrrrr}
\hline \multirow{2}{*}{ Umur } & $\begin{array}{c}\text { Freq- } \\
\text { uensy }\end{array}$ & Percent & $\begin{array}{c}\text { Valid } \\
\text { Percent }\end{array}$ & $\begin{array}{c}\text { Cumul- } \\
\text { ative }\end{array}$ \\
\hline Valid & 18 & 6 & 6 & 6 & 6 \\
& 19 & 12 & 12 & 12 & 18 \\
20 & 12 & 12 & 12 & 30 \\
21 & 21 & 21 & 21 & 51 \\
22 & 18 & 18 & 18 & 69 \\
23 & 13 & 13 & 13 & 82 \\
24 & 5 & 5 & 5 & 87 \\
25 & 8 & 8 & 8 & 95 \\
26 & 3 & 3 & 3 & 98 \\
27 & 2 & 2 & 2 & 100 \\
Total & 100 & 100 & 100 & \\
\hline
\end{tabular}

Tabel 6. Jenis Kelamin Responden Suku Jawa

\begin{tabular}{|c|c|c|c|c|c|}
\hline \multicolumn{2}{|c|}{ Jenis Kelamin } & $\begin{array}{c}\text { Frequ } \\
\text { ency }\end{array}$ & Percent & $\begin{array}{c}\text { Valid } \\
\text { Percent }\end{array}$ & $\begin{array}{c}\text { Cumulative } \\
\text { Percent }\end{array}$ \\
\hline \multirow{3}{*}{ Valid } & Laki-Laki & 87 & 87 & 87 & 87 \\
\hline & Perempuan & 13 & 13 & 13 & 100 \\
\hline & Total & 100 & 100 & 100 & \\
\hline
\end{tabular}

\subsubsection{Data Responden Suku Melayu}

Tabel 7. Umur Responden Suku Melayu

\begin{tabular}{lrrrrr}
\hline \multirow{2}{*}{ Umur } & $\begin{array}{c}\text { Freq- } \\
\text { uensy }\end{array}$ & Percent & $\begin{array}{c}\text { Valid } \\
\text { Percent }\end{array}$ & $\begin{array}{c}\text { Cumul- } \\
\text { ative }\end{array}$ \\
\hline Valid & 18 & 5 & 5 & 5 & 5 \\
& 19 & 14 & 14 & 14 & 19 \\
& 20 & 26 & 26 & 26 & 45 \\
21 & 22 & 22 & 22 & 67 \\
22 & 6 & 6 & 6 & 73 \\
23 & 11 & 11 & 11 & 84 \\
24 & 5 & 5 & 5 & 89 \\
25 & 7 & 7 & 7 & 96 \\
& & & \\
& & 4 & 4 & 4 & 100 \\
Total & 100 & 100 & 100 & \\
\hline
\end{tabular}

Tabel 8. Jenis Kelamin Responden Suku Melayu

\begin{tabular}{|c|c|c|c|c|c|}
\hline Jeni & s Kelamin & $\begin{array}{c}\text { Frequ } \\
\text { ency }\end{array}$ & Percent & $\begin{array}{c}\text { Valid } \\
\text { Percent }\end{array}$ & $\begin{array}{c}\text { Cumulative } \\
\text { Percent }\end{array}$ \\
\hline \multirow{3}{*}{ Valid } & & 75 & 75 & 75 & 75 \\
\hline & Perempuan & 25 & 25 & 25 & 100 \\
\hline & Total & 100 & 100 & 100 & \\
\hline
\end{tabular}

\subsubsection{Data Responden Suku Minang}

\begin{tabular}{lrrrrr}
\multicolumn{2}{c}{ Tabel 9. Umur Responden Suku Minang } \\
\hline \multirow{2}{*}{ Umur } & $\begin{array}{c}\text { Freq- } \\
\text { uensy }\end{array}$ & Percent & $\begin{array}{c}\text { Valid } \\
\text { Percent }\end{array}$ & $\begin{array}{c}\text { Cumul- } \\
\text { ative }\end{array}$ \\
\hline Valid & 18 & 2 & 2 & 2 & 2 \\
& 19 & 14 & 14 & 16 \\
20 & 10 & 10 & 10 & 26 \\
21 & 21 & 21 & 21 & 47 \\
22 & 24 & 24 & 24 & 71 \\
23 & 12 & 12 & 12 & 83 \\
24 & 10 & 10 & 10 & 93 \\
25 & 4 & 4 & 4 & 97 \\
26 & 3 & 3 & 3 & 100 \\
Total & 100 & 100 & 100 & \\
\hline
\end{tabular}

Tabel 10. Jenis Kelamin Responden Suku Minang

\begin{tabular}{|c|c|c|c|c|c|}
\hline Jeni & s Kelamin & $\begin{array}{c}\text { Frequ } \\
\text { ency }\end{array}$ & Percent & $\begin{array}{c}\text { Valid } \\
\text { Percent }\end{array}$ & $\begin{array}{c}\text { Cumulative } \\
\text { Percent }\end{array}$ \\
\hline \multirow{3}{*}{ Valid } & Laki-Laki & 82 & 82 & 82 & 82 \\
\hline & Perempuan & 18 & 18 & 18 & 100 \\
\hline & Total & 100 & 100 & 100 & \\
\hline
\end{tabular}

\subsubsection{Data Responden Suku Tionghoa}

\begin{tabular}{|c|c|c|c|c|c|}
\hline \multicolumn{2}{|c|}{ Umur } & $\begin{array}{l}\text { Freq- } \\
\text { uensy }\end{array}$ & Percent & $\begin{array}{c}\text { Valid } \\
\text { Percent }\end{array}$ & $\begin{array}{c}\text { Cumul- } \\
\text { ative }\end{array}$ \\
\hline \multirow[t]{10}{*}{ Valid } & 17 & 1 & 1 & 1 & 1 \\
\hline & 18 & 18 & 18 & 18 & 19 \\
\hline & 19 & 13 & 13 & 13 & 32 \\
\hline & 20 & 15 & 15 & 15 & 47 \\
\hline & 21 & 18 & 18 & 18 & 65 \\
\hline & 22 & 20 & 20 & 20 & 85 \\
\hline & 23 & 11 & 11 & 11 & 96 \\
\hline & 24 & 2 & 2 & 2 & 98 \\
\hline & 25 & 1 & 1 & 1 & 99 \\
\hline & 27 & 1 & 1 & 1 & 100 \\
\hline \multicolumn{2}{|c|}{ Total } & 100 & 100 & 100 & \\
\hline
\end{tabular}

Tabel 12. Jenis Kelamin Responden Suku Tionghoa

\begin{tabular}{|c|c|c|c|c|c|}
\hline \multicolumn{2}{|c|}{ Jenis Kelamin } & $\begin{array}{c}\text { Frequ } \\
\text { ency }\end{array}$ & Percent & $\begin{array}{c}\text { Valid } \\
\text { Percent }\end{array}$ & $\begin{array}{c}\text { Cumulative } \\
\text { Percent }\end{array}$ \\
\hline \multirow{3}{*}{ Valid } & Laki-Laki & 80 & 80 & 80 & 80 \\
\hline & Perempuan & 20 & 20 & 20 & 100 \\
\hline & Total & 100 & 100 & 100 & \\
\hline
\end{tabular}

\subsection{Pembahasan}

\subsubsection{Uji Keseragaman Data}

Uji keseragaman data dilakukan dengan menggunakan aplikasi Minitab. Pengujian dilakukan untuk mengetahui bahwa data berada dalam batas kontrol, sehingga setiap data yang keluar dari batas control harus dibuang. Pengujian dilakukan terhadap 36 data Antropometri Statis terhadap 100 responden dari ke lima suku. Adapun hasil pengujian dari uji keseragaman data terlihat pada tabel 13,14, 15 dan 16, dimana dari tabel tersebut terlihat hasil uji keseragaman data yang sudah diseragamkan. Dari pengujian yang 
dilakukan, uji keseragaman data dilakukan beberapa kali, dimana data yang keluar dari batas control (BKA dan BKB) dibuang dan kembali melakukan uji keseragaman datanya.

Tabel 13. Uji Keseragaman Data Suku Batak

\begin{tabular}{|cccrrrrl}
\hline No & Kode & N & B KA & X-max & X-min & B KB & Ket \\
\hline 1 & D1 & 99 & 180.87 & 175.6 & 155 & 154.01 & Seragam \\
2 & D2 & 97 & 168.59 & 165 & 145.8 & 144.68 & Seragam \\
3 & D3 & 98 & 153.51 & 147 & 130 & 129.07 & Seragam \\
4 & D4 & 100 & 120.13 & 117.5 & 97 & 93.98 & Seragam \\
5 & D5 & 100 & 106.5 & 105.5 & 89 & 86.15 & Seragam \\
6 & D6 & 100 & 85.54 & 85.5 & 65.5 & 62.92 & Seragam \\
7 & D7 & 99 & 70.07 & 69.5 & 54.5 & 54.14 & Seragam \\
8 & D8 & 98 & 93.33 & 92.5 & 84.5 & 84 & Seragam \\
9 & D9 & 98 & 83.34 & 82.5 & 72.5 & 71.61 & Seragam \\
10 & D10 & 100 & 71.7 & 119 & 54.6 & 52.79 & Seragam \\
11 & D11 & 99 & 39.53 & 35.6 & 20.7 & 16.86 & Seragam \\
12 & D12 & 95 & 24.15 & 24 & 10 & 6.9 & Seragam \\
13 & D13 & 100 & 65.76 & 61 & 47 & 42.21 & Seragam \\
14 & D14 & 100 & 54.16 & 51 & 37.6 & 33.66 & Seragam \\
15 & D15 & 100 & 59.15 & 58 & 41 & 38.9 & Seragam \\
16 & D16 & 100 & 52.1 & 50.9 & 33 & 29.81 & Seragam \\
17 & D17 & 99 & 51.16 & 51 & 34.5 & 31.31 & Seragam \\
18 & D18 & 100 & 41.98 & 40.5 & 25.5 & 20.75 & Seragam \\
19 & D19 & 99 & 43.15 & 41 & 27 & 24.48 & Seragam \\
20 & D20 & 99 & 29.64 & 29.4 & 14 & 11.32 & Seragam \\
21 & D21 & 98 & 30.66 & 29 & 12 & 8.54 & Seragam \\
22 & D22 & 100 & 44.62 & 42 & 28 & 23.23 & Seragam \\
23 & D23 & 100 & 45.62 & 44 & 33.5 & 30.03 & Seragam \\
24 & D24 & 100 & 89.69 & 89.2 & 70.5 & 67.86 & Seragam \\
25 & D25 & 100 & 78.08 & 78 & 57.5 & 55.42 & Seragam \\
26 & D26 & 99 & 22.87 & 22.4 & 14.9 & 14.84 & Seragam \\
27 & D27 & 100 & 20.48 & 20 & 12.5 & 12.48 & Seragam \\
28 & D28 & 100 & 20 & 22.5 & 10 & 11.86 & Seragam \\
29 & D29 & 100 & 13.43 & 12.8 & 7 & 5.41 & Seragam \\
30 & D30 & 100 & 31.75 & 30.4 & 17.9 & 15.84 & Seragam \\
31 & D31 & 100 & 12.56 & 11.9 & 7.2 & 6.97 & Seragam \\
32 & D32 & 100 & 200.84 & 195.4 & 152.7 & 146.98 & Seragam \\
33 & D33 & 100 & 112.84 & 108 & 70.7 & 61.59 & Seragam \\
34 & D34 & 100 & 225.6 & 217.2 & 183 & 178.33 & Seragam \\
35 & D35 & 100 & 140.84 & 137.9 & 108 & 105.62 & Seragam \\
36 & D36 & 100 & 87.34 & 86 & 66.5 & 63.71 & Seragam \\
\hline & & & & & & & \\
\hline
\end{tabular}

Uji kenormalan data dilakukan dengan menggunakan aplikasi SPSS dengan pengujian Kolmogrov-Smirnov Z. Dasar pengambikan keputusan dalam uji Normalitas K-S ini adalah jika nilai signifikansi (Sig.) lebih besar dari nilai $\alpha$ (0.05) maka data penelitian berdistribusi normal dan begitu juga sebaliknya, jika nilai signifikansi (Sig.) lebih kecil dari nilai $\alpha(0.05)$ maka data penelitian tidak berdistribusi normal.

Dari hasil pengujian yang dilakukan terhadap 36 data Antropometri Statis terhadap 100 responden suku Batak, Jawa, Melayu, Minang dan Tionghoa maka didapat hasil yang terlihat pada tabel 18 dan 19. Hasil tabel tersebut menunjukan bahwa setelah data dilakukan uji keseragaman data dan diuji kenormalan data maka didapat smua data terdistribusi secara normal.
Tabel 14. Uji Keseragaman Data Suku Jawa

\begin{tabular}{cccrrrrl}
\hline No & Kode & N & B KA & X-max & X-min & B KB & Ket \\
\hline 1 & D1 & 96 & 180.49 & 180 & 154.5 & 153.82 & Seragam \\
2 & D2 & 96 & 170.91 & 168 & 141.5 & 140.48 & Seragam \\
3 & D3 & 95 & 153.92 & 151 & 127.8 & 126.27 & Seragam \\
4 & D4 & 96 & 116.69 & 116.5 & 92.5 & 90.59 & Seragam \\
5 & D5 & 99 & 106.11 & 106 & 80.5 & 79.96 & Seragam \\
6 & D6 & 100 & 85.59 & 84 & 58.5 & 57.44 & Seragam \\
7 & D7 & 100 & 73.64 & 72 & 47.5 & 45.99 & Seragam \\
8 & D8 & 100 & 103.3 & 99 & 72 & 70.02 & Seragam \\
9 & D9 & 100 & 92.95 & 90.7 & 60.1 & 57.55 & Seragam \\
10 & D10 & 100 & 77.21 & 73 & 46.1 & 41.71 & Seragam \\
11 & D11 & 100 & 40.04 & 36.7 & 8.1 & 6.51 & Seragam \\
12 & D12 & 99 & 23.02 & 23 & 10.2 & 8.2 & Seragam \\
13 & D13 & 100 & 69.04 & 68 & 45 & 42.6 & Seragam \\
14 & D14 & 99 & 56.53 & 55.5 & 35 & 30.9 & Seragam \\
15 & D15 & 98 & 62.41 & 59 & 43 & 42.19 & Seragam \\
16 & D16 & 99 & 52.15 & 48.5 & 32 & 31.76 & Seragam \\
17 & D17 & 100 & 55.79 & 55 & 33.3 & 28.31 & Seragam \\
18 & D18 & 100 & 46.28 & 46 & 27.5 & 22.3 & Seragam \\
19 & D19 & 100 & 51.62 & 46 & 24.7 & 18.03 & Seragam \\
20 & D20 & 97 & 29.43 & 29 & 14 & 11.14 & Seragam \\
21 & D21 & 100 & 31.2 & 30 & 12.7 & 6.53 & Seragam \\
22 & D22 & 100 & 42.14 & 41.5 & 31.6 & 30.24 & Seragam \\
23 & D23 & 100 & 42.35 & 41.7 & 33.5 & 31.86 & Seragam \\
24 & D24 & 99 & 87.3 & 86.4 & 73 & 71.88 & Seragam \\
25 & D25 & 100 & 76.16 & 74.5 & 60.5 & 59.42 & Seragam \\
26 & D26 & 100 & 23.97 & 23 & 15 & 14.18 & Seragam \\
27 & D27 & 100 & 20.25 & 19.5 & 13.5 & 12.35 & Seragam \\
28 & D28 & 100 & 22.26 & 21.5 & 16 & 14.04 & Seragam \\
29 & D29 & 100 & 12.51 & 11.5 & 7.2 & 5.73 & Seragam \\
30 & D30 & 100 & 29.43 & 29 & 19 & 18.49 & Seragam \\
31 & D31 & 100 & 12.62 & 12.4 & 8 & 7.02 & Seragam \\
32 & D32 & 99 & 199.58 & 193.6 & 159 & 156.52 & Seragam \\
33 & D33 & 98 & 108.32 & 104.5 & 80.6 & 74.18 & Seragam \\
34 & D34 & 96 & 217.05 & 215.6 & 190.5 & 189.88 & Seragam \\
35 & D35 & 100 & 139.59 & 137.5 & 107.1 & 106.25 & Seragam \\
36 & D36 & 97 & 87.53 & 86.5 & 68 & 66.81 & Seragam \\
\hline & & & & & & & \\
\hline
\end{tabular}

Tabel 15. Uji Keseragaman Data Suku Melayu

\begin{tabular}{cccrrrll}
\hline No & Kode & N & B KA & X-max & X-min & B KB & Ket \\
\hline 1 & D1 & 99 & 182.55 & 178.5 & 154 & 152.33 & Seragam \\
2 & D2 & 99 & 171.43 & 169.5 & 143.5 & 141.97 & Seragam \\
3 & D3 & 98 & 154.69 & 151 & 128 & 127.11 & Seragam \\
4 & D4 & 97 & 116.66 & 113.5 & 93.5 & 91.85 & Seragam \\
5 & D5 & 97 & 110.39 & 107 & 86.5 & 85.07 & Seragam \\
6 & D6 & 97 & 85.82 & 83 & 63 & 62.47 & Seragam \\
7 & D7 & 100 & 74.36 & 70.9 & 50 & 49.68 & Seragam \\
8 & D8 & 100 & 114.39 & 105.5 & 76 & 72.56 & Seragam \\
9 & D9 & 100 & 102.96 & 94.2 & 65.1 & 62.51 & Seragam \\
10 & D10 & 100 & 86.94 & 119 & 48 & 46.62 & Seragam \\
11 & D11 & 98 & 47.7 & 41 & 14.5 & 13.11 & Seragam \\
12 & D12 & 100 & 28.51 & 25 & 10.9 & 5.64 & Seragam \\
13 & D13 & 100 & 66.62 & 65 & 52 & 49.58 & Seragam \\
14 & D14 & 100 & 56.76 & 55 & 42.1 & 41.41 & Seragam \\
15 & D15 & 100 & 56.87 & 55.5 & 44.9 & 43.26 & Seragam \\
16 & D16 & 100 & 47.63 & 45.5 & 35 & 34.48 & Seragam \\
17 & D17 & 99 & 46.87 & 45.5 & 37.6 & 35.23 & Seragam \\
18 & D18 & 99 & 44.18 & 43 & 34 & 32.1 & Seragam \\
19 & D19 & 99 & 40.19 & 38.1 & 25.9 & 23.65 & Seragam \\
20 & D20 & 100 & 24.32 & 23 & 15 & 13.51 & Seragam \\
21 & D21 & 99 & 24.47 & 23.3 & 15 & 13.35 & Seragam \\
22 & D22 & 97 & 41.51 & 40.5 & 31.3 & 30.39 & Seragam \\
23 & D23 & 99 & 41.71 & 41.5 & 39 & 38.15 & Seragam \\
24 & D24 & 98 & 83.65 & 81.7 & 70.5 & 69.79 & Seragam \\
25 & D25 & 97 & 73.37 & 72 & 62.7 & 61.79 & Seragam \\
26 & D26 & 97 & 19.36 & 18.5 & 16 & 15.47 & Seragam \\
27 & D27 & 98 & 18.22 & 17.1 & 13.5 & 13.08 & Seragam \\
28 & D28 & 100 & 22.96 & 22 & 15 & 14.88 & Seragam \\
29 & D29 & 99 & 10.81 & 10 & 7 & 6.85 & Seragam \\
30 & D30 & 100 & 29.38 & 28.5 & 21.3 & 20.41 & Seragam \\
31 & D31 & 99 & 11.52 & 11 & 8 & 7.35 & Seragam \\
32 & D32 & 98 & 188.01 & 186.5 & 159 & 158.06 & Seragam \\
33 & D33 & 98 & 105.11 & 99.9 & 78 & 77.62 & Seragam \\
34 & D34 & 100 & 215.5 & 185.5 & 183.16 & 222.36 & Seragam \\
35 & D35 & 100 & 142.7 & 108 & 104.45 & 153.49 & Seragam \\
36 & D36 & 97 & 77 & 66.5 & 66.18 & 78.01 & Seragam \\
\hline & & & & & & & \\
\hline & & & & & & & \\
\hline
\end{tabular}


Tabel 16. Uji Keseragaman Data Suku Minang

\begin{tabular}{cccrrrrl}
\hline No & Kode & N & B KA & X-max & X-min & B KB & Ket \\
\hline 1 & D1 & 86 & 179.7 & 176.5 & 163.5 & 161.98 & Seragam \\
2 & D2 & 87 & 171.23 & 168 & 151 & 150.59 & Seragam \\
3 & D3 & 87 & 154.37 & 151.1 & 136.5 & 135.63 & Seragam \\
4 & D4 & 86 & 117.15 & 115.5 & 101.5 & 99.02 & Seragam \\
5 & D5 & 87 & 110.43 & 107.9 & 90.5 & 90.5 & Seragam \\
6 & D6 & 87 & 90.32 & 88 & 72 & 71.29 & Seragam \\
7 & D7 & 93 & 79.5 & 76.2 & 55.5 & 55.09 & Seragam \\
8 & D8 & 100 & 100.39 & 94 & 77 & 76.67 & Seragam \\
9 & D9 & 100 & 90.77 & 84.8 & 67 & 65.81 & Seragam \\
10 & D10 & 99 & 73.91 & 119 & 53 & 51 & Seragam \\
11 & D11 & 100 & 36.15 & 32.8 & 16.2 & 15.04 & Seragam \\
12 & D12 & 100 & 25.58 & 22.5 & 10.7 & 6.48 & Seragam \\
13 & D13 & 83 & 72.53 & 67.5 & 54.5 & 54.18 & Seragam \\
14 & D14 & 82 & 58.82 & 57.8 & 48.8 & 48.58 & Seragam \\
15 & D15 & 100 & 76.19 & 69 & 45.5 & 37.96 & Seragam \\
16 & D16 & 100 & 59.94 & 54.3 & 30.3 & 22.18 & Seragam \\
17 & D17 & 100 & 55.61 & 52.4 & 37.5 & 34.05 & Seragam \\
18 & D18 & 100 & 49.72 & 45.9 & 31.3 & 28.14 & Seragam \\
19 & D19 & 100 & 48.25 & 46 & 30.4 & 28.43 & Seragam \\
20 & D20 & 99 & 27.17 & 26 & 19 & 17.01 & Seragam \\
21 & D21 & 99 & 37.12 & 36 & 16.7 & 11.47 & Seragam \\
22 & D22 & 97 & 39.85 & 39 & 29.8 & 29.04 & Seragam \\
23 & D23 & 99 & 43.55 & 43.5 & 41 & 40.57 & Seragam \\
24 & D24 & 98 & 86.02 & 84.2 & 73 & 72.42 & Seragam \\
25 & D25 & 97 & 73.77 & 72.5 & 63.2 & 62.39 & Seragam \\
26 & D26 & 100 & 22.77 & 22 & 17 & 15.36 & Seragam \\
27 & D27 & 100 & 18.91 & 18 & 12 & 10.54 & Seragam \\
28 & D28 & 97 & 22.21 & 21 & 15.5 & 15.18 & Seragam \\
29 & D29 & 99 & 10.32 & 10.1 & 7.3 & 7.08 & Seragam \\
30 & D30 & 100 & 31.1 & 30 & 18 & 17.77 & Seragam \\
31 & D31 & 100 & 12.47 & 12.2 & 8 & 6.63 & Seragam \\
32 & D32 & 98 & 207.29 & 202.3 & 171.5 & 167.74 & Seragam \\
33 & D33 & 97 & 106.42 & 100.8 & 75.6 & 72.63 & Seragam \\
34 & D34 & 76 & 217.19 & 215.5 & 209.5 & 207.44 & Seragam \\
35 & D35 & 100 & 141.03 & 136.1 & 113.5 & 111.02 & Seragam \\
36 & D36 & 97 & 78.84 & 78 & 67.5 & 67 & Seragam \\
\hline & & & & & & & \\
\hline
\end{tabular}

Tabel 17. Uji Keseragaman Data Suku Tionghoa

\begin{tabular}{cccrrrrl}
\hline No & Kode & N & B KA & X-max & X-min & B KB & Ket \\
\hline 1 & D1 & 99 & 190.3 & 185 & 153 & 151.92 & Seragam \\
2 & D2 & 99 & 177.81 & 173.5 & 140 & 139.93 & Seragam \\
3 & D3 & 99 & 162.79 & 157.5 & 126.5 & 124.04 & Seragam \\
4 & D4 & 100 & 127.09 & 123.1 & 88 & 87.85 & Seragam \\
5 & D5 & 100 & 119.81 & 115.1 & 80.2 & 80.03 & Seragam \\
6 & D6 & 99 & 95.05 & 91.6 & 58 & 57.07 & Seragam \\
7 & D7 & 100 & 81.5 & 78.6 & 42 & 40.81 & Seragam \\
8 & D8 & 100 & 109.16 & 105 & 74.5 & 71.67 & Seragam \\
9 & D9 & 100 & 96.75 & 93.5 & 62.3 & 59.6 & Seragam \\
10 & D10 & 100 & 81.86 & 119 & 46.8 & 43.58 & Seragam \\
11 & D11 & 100 & 46.66 & 43.1 & 12.5 & 7.31 & Seragam \\
12 & D12 & 99 & 22.18 & 20.7 & 11.4 & 8.51 & Seragam \\
13 & D13 & 100 & 71.11 & 69 & 48 & 46.12 & Seragam \\
14 & D14 & 100 & 60.74 & 58.5 & 37.5 & 35.47 & Seragam \\
15 & D15 & 95 & 58.58 & 58.5 & 49 & 48.48 & Seragam \\
16 & D16 & 95 & 48.67 & 46.8 & 39.1 & 38.12 & Seragam \\
17 & D17 & 100 & 50.7 & 48 & 36 & 33.63 & Seragam \\
18 & D18 & 100 & 46.96 & 44 & 31.7 & 29.56 & Seragam \\
19 & D19 & 100 & 46.79 & 42.5 & 26 & 22.54 & Seragam \\
20 & D20 & 100 & 28.1 & 24.5 & 15.5 & 12.37 & Seragam \\
21 & D21 & 100 & 29.52 & 26.5 & 15 & 12.47 & Seragam \\
22 & D22 & 97 & 42.55 & 41.5 & 32.3 & 31.35 & Seragam \\
23 & D23 & 99 & 45.72 & 45.6 & 43 & 42.52 & Seragam \\
24 & D24 & 99 & 84.56 & 81.7 & 69 & 68.72 & Seragam \\
25 & D25 & 97 & 68.13 & 66.5 & 57.2 & 56.03 & Seragam \\
26 & D26 & 99 & 22.92 & 21.6 & 15.5 & 15.45 & Seragam \\
27 & D27 & 99 & 19.08 & 17.7 & 12.8 & 12.36 & Seragam \\
28 & D28 & 100 & 24.7 & 23.5 & 15.2 & 13.72 & Seragam \\
29 & D29 & 98 & 11.57 & 10.9 & 8 & 7.59 & Seragam \\
30 & D30 & 99 & 29.09 & 28 & 22 & 21.27 & Seragam \\
31 & D31 & 100 & 12.61 & 11.8 & 7 & 6.3 & Seragam \\
32 & D32 & 99 & 197.47 & 193.8 & 162 & 161.68 & Seragam \\
33 & D33 & 97 & 105.92 & 102.9 & 81.5 & 79.58 & Seragam \\
34 & D34 & 99 & 232.26 & 227.6 & 190.5 & 189.03 & Seragam \\
35 & D35 & 100 & 150.15 & 147.6 & 109.7 & 109.66 & Seragam \\
36 & D36 & 98 & 77.65 & 76 & 64.5 & 64.29 & Seragam \\
\hline & & & & & & & \\
\hline
\end{tabular}

Tabel 18. Uji Kenormalan Data Suku Batak, Jawa dan Melayu

\begin{tabular}{|c|c|c|c|c|c|c|c|c|c|c|}
\hline \multirow[b]{2}{*}{ No } & \multirow[b]{2}{*}{ Kode } & \multicolumn{3}{|c|}{ Suku Batak } & \multicolumn{3}{|c|}{ Suku Jawa } & \multicolumn{3}{|c|}{ Suku Melayu } \\
\hline & & $\begin{array}{l}\text { Sig. (2- } \\
\text { tailed) }\end{array}$ & $\begin{array}{c}\alpha= \\
0.05\end{array}$ & $\begin{array}{c}\text { Ket (Sig } \\
>\alpha)\end{array}$ & $\begin{array}{l}\text { Sig. (2- } \\
\text { tailed) }\end{array}$ & $\begin{array}{c}\alpha= \\
0.05\end{array}$ & $\begin{array}{c}\text { Ket }(\mathrm{Sig} \\
>\alpha)\end{array}$ & $\begin{array}{l}\text { Sig. (2- } \\
\text { tailed) }\end{array}$ & $\begin{array}{c}\alpha= \\
0.05\end{array}$ & $\begin{array}{c}\text { Ket (Sig } \\
>\alpha)\end{array}$ \\
\hline 1 & D1 & 0.461 & $>\alpha$ & Normal & 0.461 & $>\alpha$ & & 0.585 & $>\alpha$ & \\
\hline 2 & & & $>\alpha$ & & & $>\alpha$ & & 0.89 & $>\alpha$ & \\
\hline 3 & & & $>\alpha$ & & & & & 658 & $>\alpha$ & \\
\hline 4 & & & $>\alpha$ & & & $>\alpha$ & & 444 & $>\alpha$ & \\
\hline 5 & & & $>\alpha$ & & & $>\alpha$ & & 0.38 & $>\alpha$ & \\
\hline 6 & & & & & & & & .596 & $>\alpha$ & \\
\hline 7 & & & $>\alpha$ & & & $>\alpha$ & & 189 & $>\alpha$ & \\
\hline 8 & & & $\alpha$ & & & 2 & & 106 & $>\alpha$ & \\
\hline & & & $\alpha$ & & & & & 181 & $>\alpha$ & \\
\hline 10 & & & $\alpha$ & & & $>\alpha$ & & 076 & $>\alpha$ & \\
\hline 1 & & & $>\alpha$ & & & $>\alpha$ & & 206 & $>\alpha$ & \\
\hline 12 & & & $\alpha$ & & & $>\alpha$ & & 139 & $>\alpha$ & \\
\hline 13 & & & $>\alpha$ & & & $>\alpha$ & & 84 & $>\alpha$ & \\
\hline 14 & & & $>\alpha$ & & & $>\alpha$ & & 432 & $>\alpha$ & \\
\hline 15 & & & $>\alpha$ & & & $>\alpha$ & & 87 & $>\alpha$ & \\
\hline & & & $\alpha$ & & & $>0$ & & 77 & $>\alpha$ & \\
\hline & & & $\alpha$ & & & 30 & & 355 & $>\alpha$ & \\
\hline & & & $\alpha$ & & & $>0$ & & 265 & $>\alpha$ & \\
\hline 15 & & & $\alpha$ & & & $>$ & & 648 & $>0$ & \\
\hline 2 & & & & & & & & 274 & $>\alpha$ & \\
\hline & & & $\alpha$ & & & $>\alpha$ & & 213 & $>\alpha$ & \\
\hline 2 & & & $>\alpha$ & & & $>\alpha$ & & 423 & $>\alpha$ & \\
\hline 2. & & & $>\alpha$ & & & $>\alpha$ & & 131 & $>\alpha$ & \\
\hline 24 & & & $>\alpha$ & & & $>\alpha$ & & 0.65 & $>\alpha$ & \\
\hline 25 & & & $>\alpha$ & & & $>\alpha$ & & 762 & $>\alpha$ & \\
\hline 26 & & & $>\alpha$ & & & $>\alpha$ & & 582 & $>\alpha$ & \\
\hline 27 & & & & & & $>\alpha$ & & 32 & $>\alpha$ & \\
\hline 28 & & & & & & $>$ & & & & \\
\hline 29 & & & & & & $>$ & & & & \\
\hline 30 & & & & & & & & & & \\
\hline 31 & & & & & & $>$ & & 102 & $>\alpha$ & \\
\hline 3 & & & $>\alpha$ & & & $>0$ & & 959 & $>\alpha$ & \\
\hline 3 & & & $>\alpha$ & & & $>0$ & & 701 & & \\
\hline 3 & & & & & & $>0$ & & & & \\
\hline 35 & & & $>\alpha$ & & & $>\alpha$ & & 0.181 & $>\alpha$ & \\
\hline 36 & D & 41 & $>\alpha$ & Normal & 641 & $>\alpha$ & Normal & 0.82 & $>\alpha$ & Normal \\
\hline
\end{tabular}

\subsubsection{Uji Kenormalan Data}

4.2.3 Uji Kecukupan Data

Jika nilai $\mathrm{N}^{\prime}<\mathrm{N}$ maka data dianggap cukup, dari hasil perhitungan yang telah dilakukan dengan menggunakan rumus uji kecukupan data sesuai dengan rumus 4 , maka semua data sudah cukup artinya jumlah responden Suku Batak, Jawa, Melayu, Minang dan Tionghoa sudah cukup untuk dijadikan sampel penelitian. Adapun hasil dari uji kecukupan data dapat dilihat pada tabel 20 dan 21.

\subsubsection{Persentil}

Tabel 2 menunjukan rumus persentil, dimana untuk mendapatkan nilai persentile maka dibutuhkan nilai rata-rata $(\dot{X})$ dan standar deviasi (SD). Sehingga dari perhitungan yang telah dilakukan terhadap nilai persentil untuk data Antropometri dari masing-masing suku dapat dilihat pada table 22, 23, 24, 25 dan 26. 
Tabel 19. Uji Kenormalan Data Suku Minang dan Tionghoa

\begin{tabular}{|c|c|c|c|c|c|c|}
\hline \multirow[b]{2}{*}{ No } & \multirow[b]{2}{*}{ Kode } & \multicolumn{3}{|c|}{ Suku Minang } & \multicolumn{2}{|c|}{ Suku Tionghoa } \\
\hline & & $\begin{array}{l}\text { Sig. (2- } \\
\text { tailed) }\end{array}$ & $\begin{array}{c}\alpha= \\
0.05\end{array}$ & $\begin{array}{c}\text { Ket (Sig } \\
>\alpha)\end{array}$ & $\begin{array}{l}\text { Sig. (2- } \\
\text { tailed) }\end{array}$ & $\begin{array}{c}\text { Ket (Sig } \\
>\alpha)\end{array}$ \\
\hline 1 & D1 & 0.722 & $>\alpha$ & Normal & 0.865 & Normal \\
\hline 2 & D2 & 0.967 & $>\alpha$ & Normal & 0.716 & Normal \\
\hline 3 & D3 & 0.926 & $>\alpha$ & Normal & 0.973 & Normal \\
\hline 4 & D4 & 0.461 & $>\alpha$ & Normal & 0.953 & Normal \\
\hline 5 & D5 & 0.665 & $>\alpha$ & Normal & 0.94 & Normal \\
\hline 6 & D6 & 0.883 & $>\alpha$ & Normal & 0.803 & Normal \\
\hline 7 & D7 & 0.666 & $>\alpha$ & Normal & 0.803 & Normal \\
\hline 8 & D8 & 0.245 & $>\alpha$ & Normal & 0.524 & Normal \\
\hline 9 & D9 & 0.306 & $>\alpha$ & Normal & 0.745 & Normal \\
\hline 10 & D10 & 0.346 & $>\alpha$ & Normal & 0.879 & Normal \\
\hline 11 & D11 & 0.491 & $>\alpha$ & ormal & 0.411 & Jormal \\
\hline 12 & D12 & 0.155 & $>\alpha$ & Normal & 0.106 & Normal \\
\hline 13 & D13 & 0.062 & $>\alpha$ & Normal & 0.635 & Normal \\
\hline 14 & D14 & 0.56 & $>\alpha$ & Normal & 0.736 & Normal \\
\hline 15 & D15 & 0.116 & $>\alpha$ & Normal & 0.056 & Normal \\
\hline 16 & D16 & 0.05 & $>\alpha$ & Normal & 0.376 & Normal \\
\hline 17 & D17 & 0.781 & $>\alpha$ & Normal & 0.098 & Normal \\
\hline 18 & D18 & 0.898 & $>\alpha$ & Normal & 0.542 & Normal \\
\hline 19 & D19 & 0.532 & $>\alpha$ & Normal & 0.864 & Normal \\
\hline 20 & D2O & 0.634 & $>\alpha$ & Normal & 0.395 & Normal \\
\hline 21 & D21 & 0.221 & $>\alpha$ & Normal & 0.375 & Normal \\
\hline 22 & D22 & 0.423 & $>\alpha$ & Normal & 0.423 & Normal \\
\hline 23 & D23 & 0.442 & $>\alpha$ & Normal & 0.122 & Normal \\
\hline 24 & D24 & 0.65 & $>\alpha$ & Normal & 0.47 & Normal \\
\hline 25 & D25 & 0.762 & $>\alpha$ & Normal & 0.762 & Normal \\
\hline 26 & D26 & 0.067 & $>\alpha$ & Normal & 0.079 & Normal \\
\hline 27 & D27 & 0.207 & $>\alpha$ & Normal & 0.59 & Normal \\
\hline 28 & D28 & 0.325 & $>\alpha$ & Normal & 0.215 & Normal \\
\hline 29 & D29 & 0.371 & $>\alpha$ & Normal & 0.329 & Normal \\
\hline 30 & D30 & 0.341 & $>\alpha$ & Normal & 0.573 & Normal \\
\hline 31 & D31 & 0.055 & $>\alpha$ & Normal & 0.203 & Normal \\
\hline 32 & D32 & 0.573 & $>\alpha$ & Normal & 0.781 & Normal \\
\hline 33 & D33 & 0.972 & $>\alpha$ & Normal & 0.962 & Normal \\
\hline 34 & D34 & 0.271 & $>\alpha$ & Normal & 0.609 & Normal \\
\hline 35 & D35 & 0.253 & $>\alpha$ & Normal & 0.674 & Normal \\
\hline 36 & D36 & 0.593 & $>\alpha$ & Normal & 0.58 & Normal \\
\hline
\end{tabular}

Tabel 20. Uji Kecukupan Data Suku Batak, Jawa dan Melayu

\begin{tabular}{|c|c|c|c|c|c|c|c|c|c|c|}
\hline \multirow[b]{2}{*}{ No } & & \multicolumn{3}{|c|}{ Suku Batak } & \multicolumn{3}{|c|}{ Suku Jawa } & \multicolumn{3}{|c|}{ Suku Melayu } \\
\hline & & $\mathbf{N}$ & $\mathbf{N}^{\prime}$ & Ket & $\mathbf{N}$ & $\mathbf{N}^{\prime}$ & Ket & $\mathbf{N}$ & $\mathbf{N}^{\prime}$ & Ket \\
\hline & D1 & 99 & 1.15 & ukup & 96 & 1.59 & Cukup & & 1.97 & Cuk \\
\hline & & & & & 96 & 2.04 & & 99 & 2.16 & \\
\hline & & & & & & 18 & & & 33 & \\
\hline & & 100 & 54 & c & 96 & 3.78 & & 97 & 3.35 & \\
\hline & & & & & 99 & 4.96 & & 97 & 4.02 & \\
\hline & & & & & 100 & 9.29 & & 7 & 6.26 & \\
\hline & & & 3.78 & & & 11.66 & & 100 & 9.9 & \\
\hline & & & 0.45 & & 100 & 6.68 & & 100 & 11.22 & \\
\hline & & & & & 100 & 10.13 & & 100 & 13.69 & ip \\
\hline 10 & & 100 & 77 & & 100 & 15.66 & & 100 & 20.2 & \\
\hline 1 & & & 23.01 & & 100 & 90.87 & & 98 & 73.32 & \\
\hline & & & 54.63 & & 99 & 45.03 & & 100 & 81.99 & \\
\hline & & & 38 & & 100 & 9.81 & & 100 & 4.3 & \\
\hline 14 & & & 41 & & 99 & 14.85 & & 100 & 4.92 & \\
\hline 15 & & 0 & & & 98 & 6.57 & & 100 & 3.92 & \\
\hline & & & & & 99 & 6 & & 100 & 5.21 & \\
\hline 1 & & & & & 100 & 21.11 & & 99 & 3.95 & \\
\hline & & & & & 10 & 23.57 & & 9 & 4.97 & \\
\hline 14 & & & & & 100 & 36.91 & & 9 & 12.66 & \\
\hline 20 & & & 4 & & 97 & 39.47 & & 100 & 13.9 & $c$ \\
\hline 21 & & & 0.29 & & 100 & 67.2 & & 99 & 14.95 & \\
\hline & & & & & & & & 97 & 4.35 & \\
\hline & & & & & 100 & & & 99 & 0.3 & \\
\hline & & & & & 99 & .04 & & 98 & 1.61 & \\
\hline & $\mathrm{D} 2$ & 10 & & & 100 & 2.95 & & 97 & 1.38 & c \\
\hline 26 & & & & & 100 & 12.47 & & 97 & 2.45 & c \\
\hline 27 & & & 3.27 & & 100 & 11.68 & & 98 & 4.87 & \\
\hline 28 & & & & & 10 & 8.77 & & 100 & 10.06 & \\
\hline 29 & & & & & 100 & 20.32 & & 99 & 9.8 & \\
\hline 3 & & & & & 100 & & & 100 & 6.68 & \\
\hline 3 & & & 16.3 & & 100 & 14.31 & & 99 & 10.4 & \\
\hline 3 & & & & & 95 & 2.67 & & 98 & 1.52 & \\
\hline 33 & & 100 & 12.58 & & 98 & 97 & & 98 & 4.11 & Cukup \\
\hline 3 & & 10 & & & 96 & 19 & & 100 & 2.08 & ukup \\
\hline 35 & D3. & 10 & 3.26 & Cukup & 100 & 3.75 & Cukup & 100 & 7.95 & Cukt \\
\hline 36 & & 100 & & Cukup & 97 & 3.4 & & 97 & 1.35 & . \\
\hline
\end{tabular}

Tabel 21. Uji Kecukupan Data Suku Minang dan Tionghoa

\begin{tabular}{|c|c|c|c|c|c|c|c|}
\hline \multirow{2}{*}{ No } & \multirow{2}{*}{ Kode } & \multicolumn{3}{|c|}{ Suku Minang } & \multicolumn{3}{|c|}{ Suku Tionghoa } \\
\hline & & $\mathbf{N}$ & $\mathbf{N}^{\prime}$ & Ket & $\mathbf{N}$ & $\mathbf{N}^{*}$ & Ket \\
\hline 1 & D1 & 86 & 0.48 & Cukup & 99 & 2.42 & Cukup \\
\hline 2 & D2 & 87 & 0.68 & Cukup & 99 & 2.76 & Cukup \\
\hline 3 & D3 & 87 & 0.75 & Cukup & 99 & 3.37 & Cukup \\
\hline 4 & D4 & 86 & 1.38 & Cukup & 100 & 6.32 & Cukup \\
\hline 5 & D5 & 87 & 1.82 & Cukup & 100 & 7.42 & Cukup \\
\hline 6 & D6 & 87 & 2.65 & Cukup & 99 & 11.51 & Cukup \\
\hline 7 & D7 & 93 & 7.17 & Cukup & 100 & 20.32 & Cukup \\
\hline 8 & D8 & 100 & 3.54 & Cukup & 100 & 7.26 & Cukup \\
\hline 9 & D9 & 100 & 4.27 & Cukup & 100 & 9.73 & Cukup \\
\hline 10 & D10 & 99 & 6.27 & Cukup & 100 & 15.08 & Cukup \\
\hline 11 & D11 & 100 & 28.58 & Cukup & 100 & 89.05 & Cukup \\
\hline 12 & D12 & 100 & 54.2 & $\mathrm{Cu}$ & 99 & 37.75 & Cukup \\
\hline 13 & D13 & 83 & 1.66 & & 100 & 7.15 & Cukup \\
\hline 14 & D14 & 82 & 1.94 & $\mathrm{Cu}$ & 100 & 11.08 & Cukup \\
\hline 15 & & 100 & 20.69 & & 95 & 1.63 & kup \\
\hline 16 & & 100 & 39.01 & & 95 & 2.28 & \\
\hline 17 & D & 100 & 10.48 & $\mathrm{Cu}$ & 100 & 7.09 & Cukup \\
\hline 18 & D & 100 & 13.77 & & 100 & 9.17 & Cukup \\
\hline 19 & D & 100 & 10.34 & $\mathrm{Cu}$ & 100 & 23.09 & Cukup \\
\hline 20 & D & 99 & 9.69 & $\mathrm{Cu}$ & 100 & 21.46 & Cukup \\
\hline 21 & D21 & 99 & 47.94 & Cukup & 100 & 28.87 & Cukup \\
\hline 22 & & 97 & 4.73 & & 97 & 4.11 & $\mathrm{Cu}$ \\
\hline 23 & D23 & 99 & 0.25 & $\mathrm{Cu}$ & 99 & 0.26 & Cukup \\
\hline 24 & D24 & 98 & 1.51 & Cukup & 99 & 1.76 & Cukup \\
\hline 25 & & 97 & 1.36 & & 97 & 1.63 & Cukup \\
\hline 26 & D & 100 & 6.97 & & 99 & 6.6 & Cukup \\
\hline 27 & D27 & 100 & 14.27 & Cuku & 99 & 8.18 & Cukup \\
\hline 28 & D28 & 97 & 6.14 & Cukup & 100 & 14.3 & Cukup \\
\hline 29 & & 99 & 7.1 & Cukup & 98 & 7.43 & Cukup \\
\hline 30 & D & 100 & 13.69 & Cuk & 99 & 3.81 & Cukup \\
\hline 31 & D31 & 100 & 14.82 & Cukup & 100 & 19.86 & Cukup \\
\hline 32 & D32 & 98 & 2.17 & Cukup & 99 & 1.61 & Cukup \\
\hline 33 & D33 & 97 & 6.32 & & 97 & 3.54 & Cukup \\
\hline 34 & D34 & 76 & 0.08 & $\mathrm{Cu}$ & 99 & 2.09 & Cukup \\
\hline 35 & & 100 & 2.93 & & 100 & 4.47 & Cukup \\
\hline 36 & D36 & 97 & 1.23 & Cukup & 98 & 1.49 & Cukup \\
\hline
\end{tabular}

Tabel 22. Persentil Suku Batak

\begin{tabular}{|c|c|c|c|c|c|c|c|c|c|c|c|c|}
\hline No & Kode & $\dot{\mathbf{X}}$ & & P1 & P2.5 & P5 & P10 & P50 & P90 & 95 & P97.5 & \\
\hline & D1 & & & & 158.6 & 160 & & & & 174.9 & & \\
\hline & & & & & & & & & & & & \\
\hline & & & & & & & & & & & & \\
\hline & & & & & & & & & & & & \\
\hline & & 5.32 & & & .38 & 90.5 & & 32 & & & & \\
\hline & & .23 & & & 449 & 67.73 & & & & 0.72 & . & \\
\hline & & & & & & & & & & & & \\
\hline & & & & & & & & & & 9 & 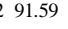 & 92 \\
\hline & & & & & & & & & &.. & 1 & \\
\hline 10 & & & & & & & & & & & 6 & \\
\hline & & & & & & & & & & & 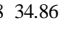 & \\
\hline & & & & & & & & & & & & \\
\hline 13 & & & & & 27 & & & & & & 60 & \\
\hline 14 & & & & & & & & & & & & \\
\hline & & & & & & & & & & & & \\
\hline 16 & & & & & & & & & & & & \\
\hline & & & & & & & & & & & 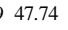 & \\
\hline & & & & & & & & & & 3 & & \\
\hline 1 & & & & & & & & & & & 10) & \\
\hline 2 & & & & & .09 & & & & & & +2 & \\
\hline 2 & & & & & & & & & & & & \\
\hline 2 & & & & & & & & & & & & \\
\hline 2 & & & & & & & & & & & & \\
\hline & & & & & & & & & & & & \\
\hline & & & & & & & & & & 7 & 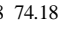 & \\
\hline 2 & & & & & & 16.41 & & & & & 1.76 & \\
\hline 2 & & & & & & & & & & 8.97 & 719.44 & \\
\hline 28 & & .83 & & 2.64 & 3.46 & 14.16 & & & & .5 & 22.2 & \\
\hline 2 & & & & & & & & & & & & \\
\hline 30 & & & & & 18.12 & 19.03 & & & & 28.56 & 5 29.4 & \\
\hline & & & & & & & & & & & & \\
\hline & & & & & & & & & & & & \\
\hline 3 & & & & & & & & & & & & \\
\hline & & & & & & & & & & & & \\
\hline & & & & & & & & & & & & \\
\hline & & & & & & 9 & & & & 82. & & \\
\hline
\end{tabular}


Tabel 23. Persentil Suku Jawa

\begin{tabular}{|c|c|c|c|c|c|c|c|c|c|c|c|c|}
\hline 0 & Kode & $\underline{X}$ & SD & P1 & 2.5 & P5 & P10 & $P 50$ & & & & \\
\hline & D1 & 167.2 & 3 & & & & & 167.2 & & & 177.5 & \\
\hline & & & & & & & & & & & & \\
\hline & & H0.1 & & & & & & & & & & \\
\hline & D4 & 3.6 & 06 & & & & & & & & & \\
\hline & & 3.03 & & & & & & & & & & \\
\hline & & 1.52 & & & & & & & & & & \\
\hline & & & & & & & & & & & & \\
\hline & & 86.66 & & & & & & & & & & \\
\hline & & & & & & & & & & & & \\
\hline & & .40 & & & & & & & & & & \\
\hline & & & & & & & & & & & & \\
\hline & & .61 & & & & & & & & & & \\
\hline & & & & & & & & & & & & \\
\hline & & .71 & & & & & & & & & & \\
\hline & & & & & & & & & & & & \\
\hline & & & & & & & & & & & & \\
\hline & & & & & & & & & & & & \\
\hline & & & & & & & & & & & & \\
\hline & & & & & & & & & & & & \\
\hline & & & & & & & & & & & & \\
\hline & & & & & & & & & & & & \\
\hline & & & & & & & & & & & & \\
\hline & & & & & & & & & & & & \\
\hline & & & & & & & & & & & & \\
\hline & & & & & & & & & & & & \\
\hline & & & & & & & & & & & & \\
\hline 2 & & & & & .56 & & & & & & & \\
\hline 28 & & & & & & & & & & & & \\
\hline 2 & & & & & & & & & & & & \\
\hline & & & & & & & & & & & & \\
\hline & & & & & & & & & & & & \\
\hline & & & & & & & & & & & & \\
\hline & & & & & & & & & & & & \\
\hline 3 & & & & & & & & & & & & \\
\hline 3 & & & & & & & & & & & & \\
\hline$\pi$ & & & 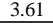 & 00.1 & (1.1. & $1.2 \mathrm{r}$ & 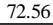 & 11.11 & 01.19 & 0.1 & 184.24 & or. \\
\hline
\end{tabular}

Tabel 24. Persentil Suku Melayu

\begin{tabular}{|c|c|c|c|c|c|c|c|c|c|c|c|c|}
\hline No & Kode & $\dot{\mathrm{X}}$ & SD & P1 & P2.5 & P5 & P10 & P50 & P90 & P95 & P97.5 & \\
\hline & D1 & 167.4 & 5.9 & & & 157.7 & & 167.4 & & 177.1 & 1179 & \\
\hline & D2 & 156.7 & & & & & & & & & & \\
\hline & & 40.9 & & & & & & & & & & \\
\hline & & 4.3 & & & & & & & & & & \\
\hline & & 7.73 & & & & & & & & & & \\
\hline & & 74.14 & & & & & & & & & .2 & \\
\hline & D & 62.02 & 4.9 & & & & & & & & & \\
\hline & D & 93.48 & & & & & & & & & & \\
\hline & & 82.74 & & & & & & & & & & \\
\hline & & .78 & & & & & & & & & & \\
\hline & & 0.41 & & & & & & & & & & \\
\hline & & 17.07 & & & & & & & & & .08 & 6.1 \\
\hline 13 & & 58.1 & & & & & & & & & & \\
\hline 14 & & 49.09 & & & & & & & & & & \\
\hline & & & & & & & & & & & & \\
\hline 10 & & 1.05 & & & & & & & & & & \\
\hline $1 /$ & & 1.05 & & & & & & & & & & \\
\hline 18 & & 3.14 & & & & & & & & & & \\
\hline & & & & & & & & & & & & \\
\hline 20 & & 3.92 & & & & & & & & & & \\
\hline 21 & & .91 & & & & & & & & & & \\
\hline 22 & & .95 & & & & & & & & & & \\
\hline 23 & & 39.93 & & & & 39.02 & & & & & +4 & \\
\hline & & 5.72 & & & & & & & & & & \\
\hline & & 7.58 & & & & & & & & & & \\
\hline 2 & & 1.42 & & & & & & & & & & \\
\hline 27 & & & & & & & & & & & & \\
\hline 28 & & 18.92 & & & & 16.44 & & & & 4 & 8 & \\
\hline 29 & & & & & & & & & & & .47 & \\
\hline 30 & & 24.92 & 62 & 21.16 & 21.75 & 22.26 & 22.85 & 92 & 6.99 & 58 & 28.09 & 28 \\
\hline & & 9.44 & & & & & & & & & & \\
\hline & & & & & & & & & & & & \\
\hline & & & & & & & & & & & & \\
\hline & & 202.8 & & & & & & & & & & \\
\hline 3. & & 129 & & & & & $117 . .3$ & 129 & 140 & 144 & +146 & \\
\hline 36 & & 2.1 & & & 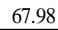 & 8.6 & $c_{0}$ & 12.1 & & - & 0.2 & 76.9 \\
\hline
\end{tabular}

Tabel 25. Persentil Suku Minang

\begin{tabular}{|c|c|c|c|c|c|c|c|c|c|c|c|c|}
\hline No & de & $\dot{\mathbf{x}}$ & D & P1 & P2.5 & P5 & P10 & P50 & P90 & & & \\
\hline 1 & D1 & 170.8 & 97 & & 165 & 166 & 167 & 70.8 & 74.7 & 175.7 & 176.7 & 177.8 \\
\hline 2 & D2 & 160.9 & 3.33 & & 8.4 & & 156.7 & 60.9 & & & & \\
\hline 3 & D3 & 145 & 3.16 & & 138.8 & 139.8 & 141 & 145 & & & & 52.4 \\
\hline 4 & D4 & 108.1 & 3.19 & & & 102.8 & 104 & & & 13.3 & 14.3 & 15.5 \\
\hline 5 & D5 & 100.5 & 3.41 & .54 & 93.79 & 94.86 & 96.1 & 100.5 & & 106.1 & 107. & 108 \\
\hline 6 & D6 & 80.8 & 3.31 & 11 & 74.32 & 75.36 & 76.57 & 80.8 & & 86.25 & 87.29 & 88. \\
\hline 7 & D7 & 67.3 & 4.53 & & & 9.85 & 61.5 & & & & & 77. \\
\hline 8 & & 3.03 & 4.16 & & .87 & 18 & 82. & & & & & \\
\hline 9 & & 3.29 & 4.06 & & & 1.6 & 3.09 & & & & 0.2. & 7.14 \\
\hline 10 & 10 & 2.45 & 3.93 & & .75 & & 57.43 & & $6 / .48$ & & & 1.59 \\
\hline 11 & 11 & 25.6 & 3.44 & & 86 & & 21.2 & 5.6 & 30 & .26 & 2.3 & 3.5 \\
\hline 12 & 12 & 16.03 & 2.96 & 9.14 & .22 & & 12.23 & 03 & & 2 & 1.84 & 2.92 \\
\hline 13 & D13 & 64.22 & 2.08 & & 60.13 & & 1.55 & & .88 & 67.64 & 8.3 & .06 \\
\hline 14 & 14 & 3.7 & 1.88 & & .01 & 0.6 & 1.29 & & .11 & 56 & 7.39 & 8.08 \\
\hline 15 & D15 & 57.07 & 6.52 & & 4.29 & 46.34 & 48.72 & 5 & 5.42 & 67.8 & 69.80 & 72.24 \\
\hline 16 & D16 & 41.06 & 6.44 & & & & & & 4 & 51.6 & & 56.04 \\
\hline 17 & 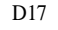 & 4.83 & 3.65 & & & & & & $\begin{array}{l}9 . \\
.3\end{array}$ & 50.8 & & 53.31 \\
\hline 18 & & 8.93 & 3.63 & & .82 & & 34.29 & & 4 & 44.9 & & $\begin{array}{l}77.37 \\
\end{array}$ \\
\hline 19 & & 38.34 & 3.1 & & 32.27 & & 34.3 & & 2. & 43.43 & & 5.54 \\
\hline 20 & D20 & 22.09 & 1.73 & & 18.7 & & 19.88 & 22.09 & 24.3 & 24.93 & 25.4 & 26.11 \\
\hline 21 & D21 & 24.3 & 4.23 & & & & 18.89 & 24.3 & 29.71 & 31.25 & 32.58 & 34.12 \\
\hline 22 & D22 & 34.45 & 1.88 & 30.07 & 30.76 & 31.35 & 32.04 & 34.45 & 36.86 & 37.55 & 38.14 & +38.83 \\
\hline 23 & D23 & 42.06 & 0.53 & & .02 & 19 & 41.38 & 4 & 4 & 42.93 & 43. & 13.29 \\
\hline 24 & D24 & 79.22 & 2.44 & & .43 & 75.2 & 76.09 & & 8 & 83.24 & 84.01 & 84. \\
\hline 25 & D25 & 68.08 & 1.99 & 45 & & 4.8 & 65.53 & & 7 & 71.36 & 71.9 & 72.71 \\
\hline 26 & D2C & 9.06 & 1.26 & & & & 17.44 & & 2 & 21.1 & 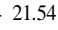 & 22 \\
\hline 27 & I & 14.73 & 1.4 & & & 43 & 12.94 & 1 & & 17.02 & 17.4 & 17.98 \\
\hline 28 & 28 & 18.7 & 1.16 & 15.99 & 16.42 & 16.78 & 17.21 & 1 & 0.19 & 20.61 & 20.98 & 821.41 \\
\hline 29 & 29 & 8.7 & 58 & 7.56 & 7.56 & 7.56 & 7.56 & 56 & 7.56 & 7.56 & 7.56 & 7.56 \\
\hline 30 & D30 & 24.44 & 2.27 & 19.15 & 19.98 & 20.7 & 21.53 & 24.44 & 27.34 & 28.17 & 28.89 & 29.72 \\
\hline 31 & D31 & 9.55 & 0.92 & 7.4 & 7.74 & 8.03 & 8.37 & 9.55 & 10.73 & 11.07 & 11.36 & $\begin{array}{ll}5 & 11.7\end{array}$ \\
\hline 32 & D32 & 37.5 & 6.93 & & 173.9 & 176.1 & 178.6 & 187.5 & 196.4 & 198.9 & 201.1 & 203.6 \\
\hline 3. & D33 & 89.52 & 5.66 & & & .22 & 82.28 & & 9 & 98.83 & 100 & 102.7 \\
\hline 3 & & & 1 & & & & 21 & & & 4.8 & & \\
\hline 35 & & 126 & 5.4 & & & & 119.1 & 126 & 133 & 134.9 & 136.6 & 5138.6 \\
\hline 36 & 36 & 72.92 & 2.03 & & & 69.58 & 70.32 & 72.92 & 75.52 & 76.26 & 76.9 & 77.6 \\
\hline
\end{tabular}

Tabel 26. Persentil Suku Tionghoa

\begin{tabular}{|c|c|c|c|c|c|c|c|c|c|c|c|c|}
\hline 5 & & $x$ & & P1 & P2.5 & 5 & 10 & 50 & & & & \\
\hline & $\overline{\mathrm{D} 1}$ & 1.1 & & & 58 & 160.1 & 2.6 & 1.1 & 179.7 & 82.1 & 44.2 & 6. \\
\hline & D2 & & & & & & & & & & & \\
\hline & & & & & & & & & & & & \\
\hline & & & & & & & & & & & & \\
\hline & & & & & & & & & & & & \\
\hline & & 06 & & & & & & & & & & \\
\hline & D7 & 61.15 & & & & & & & & & & \\
\hline & $\mathrm{D}$ & 90.41 & & & & .34 & & & & & & \\
\hline & & 8.17 & & & & & & & & & & \\
\hline & & .72 & & & & & & & & & & \\
\hline & & 98 & & & 14.44 & & & & & & & \\
\hline & & & & & & & & & & & & \\
\hline & & 62 & & & & & & & & 03 & & .77 \\
\hline 14 & & & & & & & & & & 54. & & 4. \\
\hline 1. & & & & & & & & & & & & \\
\hline & & & & & & & & & & & & \\
\hline & & & & & & & & & & & & \\
\hline & & & & & & & & & & & & \\
\hline & & & & & & & & & & & & \\
\hline & & & & & & & & & & & & \\
\hline & & & & & & & & & & & & \\
\hline & & & & & & & & & & & & \\
\hline & & & & & & & & & & & & \\
\hline & & & & & & & & & & & & \\
\hline & & & & & & & & & & & & \\
\hline & & & & & & & & & & & & \\
\hline & & & & & & & & & & & & \\
\hline & & 19.2 & & & 15.63 & 16.21 & & & & 22. & & \\
\hline & & & & & & & & & & & 29 & \\
\hline 30 & & 25.18 & & & 22.76 & 23.15 & & & 26.76 & 27.21 & 6 & \\
\hline & & & & & & & & & & & & \\
\hline & & & & & & & & & & & 0.8 & 2. \\
\hline & & & & & & & & & & & & \\
\hline & & & & & & & & & & & & \\
\hline & & & & & & & & & & & & \\
\hline & & & & & & & & & & & & \\
\hline
\end{tabular}


4.2.3 Perbandingan Data Antropometri

Tabel 27. Hasil Uji Perbandingan Data Antropometri Dari ke 5 Suku

\begin{tabular}{|c|c|c|c|c|c|c|}
\hline No & Data Antropometri & Kode & $\mathbf{F}$ & Sig. & $\begin{array}{c}\alpha= \\
0.05\end{array}$ & Ket \\
\hline 1 & Tinggi Tubuh & D1 & 13.56 & 0 & $<\alpha$ & Berbeda \\
\hline 2 & Tinggi Mata & D2 & 14.84 & 0 & $<\alpha$ & Berbeda \\
\hline 3 & Tinggi Bahu & D3 & 14.68 & 0 & $<\alpha$ & Berbeda \\
\hline 4 & Tinggi Siku & D4 & 15.17 & 0 & $<\alpha$ & Berbeda \\
\hline 5 & Tinggi Pinggul & D5 & 34.93 & 0 & $<\alpha$ & Berbeda \\
\hline 6 & Tinggi Tulang Ruas & D6 & 44.72 & 0 & $<\alpha$ & Berbeda \\
\hline 7 & Tinggi Ujung Jari & D7 & 29.88 & 0 & $<\alpha$ & Berbeda \\
\hline 8 & Tinggi Dalam Posisi Duduk & D8 & 22.79 & 0 & $<\alpha$ & Berbeda \\
\hline 9 & Tinggi Mata Dalam Posisi Duduk & D9 & 24.13 & 0 & $<\alpha$ & Berbeda \\
\hline 10 & Tinggi Bahu Dalam Posisi Duduk & D10 & 22.39 & 0 & $<\alpha$ & Berbeda \\
\hline 11 & Tinggi Siku Dalam Posisi Duduk & D11 & 25.86 & 0 & $<\alpha$ & Berbeda \\
\hline 12 & Tebal Paha & D12 & 5.32 & 0 & $<\alpha$ & Berbeda \\
\hline 13 & Panjang Lutut & D13 & 108.51 & 0 & $<\alpha$ & Ber \\
\hline 14 & Panjang Popliteal & D14 & 135.50 & 0 & $<\alpha$ & Berbeda \\
\hline 15 & Tinggi Lutut & D15 & 64.89 & 0 & $<\alpha$ & Berbeda \\
\hline 16 & Tinggi Popliteal & D16 & 6.73 & 0 & $<\alpha$ & Berbeda \\
\hline 17 & Lebar Sisi Bahu & D17 & 19.04 & 0 & $<\alpha$ & Berbeda \\
\hline 18 & Lebar Bahu Bag & D18 & 95.45 & 0 & $<\alpha$ & beda \\
\hline 19 & Lebar Pinggul & D19 & 36.55 & 0 & $<\alpha$ & zeda \\
\hline 20 & Tebal Dada & D20 & 19.53 & 0 & $<\alpha$ & Berbeda \\
\hline 21 & Tebal Perut & D21 & 43.40 & 0 & $<\alpha$ & Berbeda \\
\hline 22 & Panjang Lenge & $\mathrm{D} 22$ & 30.53 & 0 & $<\alpha$ & Berbeda \\
\hline 23 & Panjang Lengan Bawah & D23 & 383.43 & 0 & $<\alpha$ & Berbeda \\
\hline 24 & Panjang Rentang Tangan Ke Depan & D24 & 24.34 & 0 & $<\alpha$ & Berbeda \\
\hline 25 & $\begin{array}{l}\text { Panjang Bahu-Genggaman Tangan } \\
\text { Ke Depan }\end{array}$ & D25 & 86.29 & 0 & $<\alpha$ & Berbeda \\
\hline 26 & Panjang Kepala & D26 & 30.41 & 0 & $<\alpha$ & Berbeda \\
\hline 27 & Lebar Kepala & D27 & 28.78 & 0 & $<\alpha$ & Berb \\
\hline 28 & Panjang Tangan & D28 & 11.51 & 0 & $<\alpha$ & Berbeda \\
\hline 29 & Lebar Tangan & D29 & 17.81 & 0 & $<\alpha$ & Berbeda \\
\hline 30 & Panjang Kaki & D30 & 7.93 & 0 & $<\alpha$ & Berbeda \\
\hline 31 & Lebar Kaki & D31 & 3.54 & 0.01 & $<\alpha$ & Berbeda \\
\hline 32 & $\begin{array}{l}\text { Panjang Rentangan Tangan Ke } \\
\text { Samping }\end{array}$ & D32 & 68.87 & 0 & $<\alpha$ & Berbeda \\
\hline 33 & Panjang Rentangan Siku & D33 & 13.50 & 0 & $<\alpha$ & Berbeda \\
\hline 34 & $\begin{array}{l}\text { Tinggi Genggaman Tangan Ke Atas } \\
\text { Dalam Posisi Berdiri }\end{array}$ & D34 & 50.08 & 0 & $<\alpha$ & Berbeda \\
\hline 35 & $\begin{array}{l}\text { Tinggi Genggaman Ke Atas Dalam } \\
\text { Posisi Duduk }\end{array}$ & D35 & 22.54 & 0 & $<\alpha$ & Berbeda \\
\hline 36 & $\begin{array}{l}\text { Panjang Genggaman Tangan Ke } \\
\text { Depan }\end{array}$ & D36 & 75.02 & 0 & $<\alpha$ & Berbeda \\
\hline
\end{tabular}

Dari uji banding yang dilakukan dengan pengujian Anova, maka didapat perbedaan data Antropometri Statis dari kelima suku yang terlihat pada tabel 27. Dari tabel tersebut terlihat bahwa semua data antropometri berbeda, dimana semua nilai Sig. yang didapat kecil dari nilai $\alpha(0.05)$ yang berarti terdapat perbedaan data Antropometri antara kelima suku yang diukur yaitu Suku Batak, Jawa, Melayu, Minang dan Tionghoa.

Setelah dilakuka pengujian Anova antara kelima suku yang ada, maka hasil berikutnya memperlihatkan perbedaan dari masing-masing suku yang terlihat pada table 28 dan 29. Dari hasil pengujian yang telah dilakukan, didapat antara Suku Batak dan Jawa adalah 19 jenis data Antropometri sama dan 17 data berbeda, antara Suku Batak dan Melayu adalah 14 jenis data sama dan 22 data berbeda, antara Suku Batak dan Minang adalah 12 jenis data sama dan 24 data berbeda, antara Suku Batak dan Tionghoa adalah 14 jenis data sama dan 22 data berbeda, antara Suku Jawa dan Melayu adalah 12 jenis data sama dan 24 data berbeda, antara Suku Jawa dan Minang adalah 12 jenis data sama dan 24 data berbeda, antara Suku Jawa dan Tionghoa adalah 12 jenis data sama dan 24 data berbeda, antara Suku
Melayu dan Minang adalah 9 jenis data sama dan 27 data berbeda, antara Suku Melayu dan Tionghoa adalah 14 jenis data sama dan 22 data berbeda, antara Suku Minang dan Tionghoa adalah 14 jenis data sama dan 22 data berbeda. Secara umum setiap produk yang dibuat dengan pertimbangan antropometri pengguna dapat didasarkan pada prinsip dasar: untuk ukuran ratarata, untuk ukuran terbesar/ terkecil, atau untuk ukuran dengan range tertentu. Maka hasil penelitian ini dapat diaplikasikan untuk memenuhi hampir seluruh kebutuhan data pengukuran guna mendesain mesin-mesin, peralatan dan tempat kerja yang memadai. Hal ini penting untuk diperhatikan karena setiap produk itu harus aman dan nyaman untuk dipergunakan oleh penggunanya (Umami, 2017). Oleh karena itu, kesesuaian antara produk dan antropometri pengguna merupakan faktor yang sangat penting untuk diperhatikan.

Tabel 28. Uji Banding Dari Masing-masing Suku

\begin{tabular}{|c|c|c|c|c|c|c|}
\hline No & Data Antropometri & $\begin{array}{c}\text { Batak - } \\
\text { Jawa }\end{array}$ & $\begin{array}{l}\text { Batak - } \\
\text { Melayu }\end{array}$ & $\begin{array}{l}\text { Batak- } \\
\text { Minang }\end{array}$ & $\begin{array}{l}\text { Batak- } \\
\text { Tionghoa }\end{array}$ & $\begin{array}{c}\text { Jawa- } \\
\text { Melayu }\end{array}$ \\
\hline 1 & Tinggi Tubuh & Sama & Sama & Berbeda & Berbeda & Sama \\
\hline 2 & Tinggi Mata & Sama & Sama & Berbeda & Berbeda & Sama \\
\hline 3 & Tinggi Bahu & Sama & Sama & Berbeda & Sama & Sama \\
\hline 4 & Tinggi Siku & Berbeda & Berbeda & Sama & Sama & Sama \\
\hline 5 & Tinggi Pinggul & Berbeda & Sama & Berbeda & Berbeda & Berbeda \\
\hline 6 & Tinggi Tulang Ruas & Berbeda & Sama & Berbeda & Sama & Berbeda \\
\hline 7 & Tinggi Ujung Jari & Berbeda & Sama & Berbeda & Sama & Berbeda \\
\hline 8 & Tinggi Dalam & Berbeda & Berbeda & Sama & Sama & Berbeda \\
\hline 9 & Tinggi Mata D & Berbeda & Berbeda & Sama & Sama & Berbeda \\
\hline 10 & Tinggi Bahu Dalam Posisi Duduk & Berbeda & Berbeda & Sama & Sama & Berbeda \\
\hline 11 & Tinggi Siku Dal & Berbeda & Berbeda & Berbeda & Sama & Berbeda \\
\hline 12 & Tebal Paha & Sama & Berbeda & Sama & Sama & Berbeda \\
\hline 13 & Panjang Lutut & Berbeda & Berbeda & Berbeda & Berbeda & Berbeda \\
\hline 14 & Panjang $\mathrm{P}$ & Sama & Berbeda & Berbeda & Berbeda & Berbeda \\
\hline 15 & Tinggi & Berbeda & Sama & Berbeda & Berbeda & Berbeda \\
\hline 16 & Tinggi Po & Sama & Sama & Sama & Berbeda & Sama \\
\hline 17 & Lebar Sisi Bahu & Sama & Sama & Berbeda & Sama & Sama \\
\hline 18 & Lebar Ba & Berbeda & Berbeda & Berbeda & Berbeda & Berbeda \\
\hline 19 & Lebar Ping & Sama & Berbeda & Berbeda & Sama & Berbeda \\
\hline 20 & Tebal Dad & Sama & Berbeda & Berbeda & Sama & Berbeda \\
\hline 21 & Tebal F & Sama & Sama & Berbeda & Berbeda & Sama \\
\hline 22 & Panjan & Berbeda & Berbeda & Sama & Berbeda & Sama \\
\hline 23 & Panjang Le & Berbeda & Berbeda & Berbeda & Berbeda & Berbeda \\
\hline 24 & $\begin{array}{l}\text { Panjang Rentang Tangan Ke } \\
\text { Depan }\end{array}$ & Sama & Berbeda & Sama & Berbeda & Berbeda \\
\hline 25 & $\begin{array}{l}\text { Panjang Bahu-Genggaman } \\
\text { Tangan Ke Depan }\end{array}$ & Berbeda & Sama & Berbeda & Berbeda & Sama \\
\hline 26 & Panjang Kepala & Sama & Berbeda & Sama & Sama & Berbeda \\
\hline 27 & Lebar & Sama & Berbeda & Berbeda & Berbeda & Berbeda \\
\hline 28 & Panjar & Sama & Berbeda & Berbeda & Berbeda & Berbeda \\
\hline 29 & & Sama & Berb & Berbeda & Sama & \\
\hline 30 & Panjang Kaki & Sama & Berbeda & Sama & Berbeda & Berbeda \\
\hline 31 & Lebar Kaki & Sama & Sama & Sama & Sama & Berbeda \\
\hline 32 & $\begin{array}{l}\text { Panjang Rentangan Tangan Ke } \\
\text { Samping }\end{array}$ & Berbeda & Sama & Berbeda & Berbeda & Berbeda \\
\hline 33 & Panjang Rentangan Siku & Berbeda & & Sama & Berbeda & Sama \\
\hline 34 & $\begin{array}{l}\text { Tinggi Genggaman Tangan Ke } \\
\text { Atas Dalam Posisi Berdiri }\end{array}$ & Sama & Sama & Berbeda & Berbeda & Sama \\
\hline 35 & $\begin{array}{l}\text { Tinggi Genggaman Ke Atas } \\
\text { Dalam Posisi Duduk }\end{array}$ & Sama & Berbeda & Berbeda & Berbeda & Berbeda \\
\hline 36 & $\begin{array}{l}\text { Panjang Genggaman Tangan Ke } \\
\text { Depan }\end{array}$ & Berbeda & Berbeda & Berbeda & Berbeda & Berbeda \\
\hline
\end{tabular}


Tabel 29. Uji Banding Dari Masing-masing Suku

\begin{tabular}{|c|c|c|c|c|c|c|}
\hline No & Data Antropometri & $\begin{array}{c}\text { Jawa- } \\
\text { Minang }\end{array}$ & $\begin{array}{l}\text { Jawa- } \\
\text { Tionghoa }\end{array}$ & $\begin{array}{l}\text { Melayu- } \\
\text { Minang }\end{array}$ & $\begin{array}{l}\text { Melayu- } \\
\text { Tionghoa }\end{array}$ & $\begin{array}{l}\text { Minang- } \\
\text { Tionghoa }\end{array}$ \\
\hline 1 & Tinggi Tubuh & Berbeda & Berbeda & Berbeda & Berbeda & Sama \\
\hline 2 & Tinggi Mata & Berbeda & Berbeda & Berbeda & Sama & Sama \\
\hline 3 & Tinggi Bahu & Berbeda & Berbeda & Berbeda & Berbeda & Sama \\
\hline 4 & Tinggi Siku & Berbeda & Berbeda & Berbeda & Berbeda & Sama \\
\hline 5 & Tinggi Pinggul & Berbeda & Berbeda & Berbeda & Sama & Sama \\
\hline 6 & Tinggi Tulang Ruas & Berbeda & Berbeda & Berbeda & Sama & Berbeda \\
\hline 7 & Tinggi Ujung Jari & Berbeda & Sama & Berbeda & Sama & Berbeda \\
\hline 8 & Tinggi Dalam Posisi Duduk & Sama & Berbeda & Berbeda & Berbeda & Berbeda \\
\hline 9 & Tinggi Mata Dalam Posisi Duduk & Berbeda & Berbeda & Berbeda & Berbeda & Sama \\
\hline 10 & Tinggi Bahu Dalam Posisi Duduk & Berbeda & Berbeda & Berbeda & Berbeda & Sama \\
\hline 11 & Tinggi Siku Dalam Posisi Duduk & Berbeda & Berbeda & Berbeda & Berbeda & Sama \\
\hline 12 & Tebal Paha & Sama & Sama & Sama & Berbeda & Sama \\
\hline 13 & Panjang Lutut & Berbeda & Berbeda & Berbeda & Sama & Berbeda \\
\hline 14 & Panjang Popliteal & Berbeda & Berbeda & Berbeda & Sama & Berbeda \\
\hline 15 & Tinggi Lutut & Berbeda & Berbeda & Berbeda & Berbeda & Berbeda \\
\hline 16 & Tinggi Popliteal & Sama & Berbeda & Sama & Berbeda & Berbeda \\
\hline 17 & Lebar Sisi Bahu & Berbeda & Sama & Berbeda & Berbeda & Berbeda \\
\hline 18 & Lebar Bahu Bagian Atas & rbeda & Berbeda & Sama & Sama & Sama \\
\hline 19 & Lebar Pinggul & Berbeda & Sama & Berbeda & Berbeda & Berbeda \\
\hline 20 & Tebal Dada & Berbeda & Sama & Berbeda & Berbeda & Berbeda \\
\hline 21 & Tebal Perut & Berbeda & Berbeda & Berbeda & Berbeda & Berbeda \\
\hline 22 & Panjang Lengan Atas & Berbeda & Sama & Berbeda & Berbeda & Berbeda \\
\hline 23 & Panjang Lens & Berbeda & Berbeda & Berbeda & Berbeda & Berbeda \\
\hline 24 & $\begin{array}{l}\text { Panjang Rentang Tangan Ke } \\
\text { Depan }\end{array}$ & Sama & Berbeda & Berbeda & Sama & Berbeda \\
\hline 25 & $\begin{array}{l}\text { Panjang Bahu-Genggaman } \\
\text { Tangan Ke Depan }\end{array}$ & Sama & Berbeda & Sama & Berbeda & Berbeda \\
\hline 26 & Panjang Kepala & Sama & Sama & Berbeda & Berbeda & Sama \\
\hline 27 & Lebar Kepala & Berbeda & Berbeda & Berbeda & Sama & Berbeda \\
\hline 28 & Panjang Tangan & erbeda & Berbeda & Sama & Sama & Sama \\
\hline 29 & Lebar Tangan & Berbeda & Berbeda & Sama & Berbeda & Berbeda \\
\hline 30 & Panjang Kaki & Sama & Berbeda & Sama & Sama & Berbeda \\
\hline 31 & Lebar Kaki & Sama & Sama & Sama & Sama & Sama \\
\hline 32 & $\begin{array}{l}\text { Panjang Rentangan Tangan Ke } \\
\text { Samping }\end{array}$ & & Sama & Berbeda & Berbeda & Berbeda \\
\hline 33 & Panjang Rentangan Siku & Sama & Sama & Sama & Sama & Berbeda \\
\hline 34 & $\begin{array}{l}\text { Tinggi Genggaman Tangan Ke } \\
\text { Atas Dalam Posisi Berdiri }\end{array}$ & Berbeda & Berbeda & Berbeda & Berbeda & Sama \\
\hline 35 & $\begin{array}{l}\text { Tinggi Genggaman Ke Atas } \\
\text { Dalam Posisi Duduk }\end{array}$ & Berbeda & Berbeda & Berbeda & Sama & Berbeda \\
\hline 36 & $\begin{array}{l}\text { Panjang Genggaman Tangan Ke } \\
\text { Depan }\end{array}$ & Berbeda & Berbeda & Berbeda & Berbeda & Berbeda \\
\hline
\end{tabular}

\section{Kesimpulan dan Saran}

\subsection{Kesimpulan}

Berdasarkan hasil penelitian yang telah dilakukan terhadap pengukuran data Antropometri dari 5 suku di Indonesia yang ada di Kota Batam yaitu Suku Batak, Jawa, Melayu, Minang dan Tionghoa maka didapat perbedaan data Antropometri dari semua suku. Dimana dari uji banding yang dilakukan dengan pengujian Anova, didapat semua pengujian (36 data Antropometri Statis) dengan nilai Sig. kecil dari nilai $\alpha(0.05)$ yang berarti terdapat perbedaan yang signifikan.

\subsection{Saran}

Berdasarkan hasil penelitian, maka saran yang dapat diberikan adalah:

1. Diharapkan hasil pengukuran antropometri statis ini dapat dijadikan pertimbangan dalam mendesain sesuatu yang berhubungan langsung dengan manusia seperti produk, stasiun kerja, handtools dan lain-lain, yang akan dipasarkan di Indonesia.

2. Diharapkan hasil penelitian ini bisa dimasukan kedalam database Antropometri Indonesia khususnya untuk suku Batak, Jawa, Melayu, Minang dan Tionghoa.

3. Untuk penelitian selanjutnya bisa dilakukan pengujian perbedaan antropometri berdasarkan kebiasaan, pekerjaan, sosio ekonomi dan lainnya.

\section{DAFTAR PUSTAKA}

Ball, R., Shu, C., Xi, P., Rioux, M., Luximon, Y., \& Molenbroek, J. (2010). A comparison between Chinese and Caucasian head shapes q. Applied Ergonomics, 41(6), 832-839. https://doi.org/10.1016/j.apergo.2010.02.00 2

D.A., J., \& Shahnavaz, A. H. (1989). Body size variability between people in developed and developing countries and its impact on the use of imported goods. International Journal of Industrial Ergonomics, 4(2), 139-149. https://doi.org/https://doi.org/10.1016/01698141(89)90040-1

Eko Nurmianto. (2005). Ergonomi, Konsep Dasar dan Aplikasi (II). Surabaya: Guna Widya.

Esmika, A. (2015). Perbandinga Antropometri Tangan Mahasiswa Indonesia Berdasarkan Tiga Suku Terbesar di Indonesia. Universitas Gajah Mada.

Fauzan, G. M., Manela, C., \& Hidayat, T. (2019). Perbedaan Rerata Indeks Cephalic dan Indeks Frontoparietal antara Suku Minangkabau dan Suku Jawa. 8(1), 96-102.

Jahanshahi, M., Golalipour, M. J., \& Haidari, K. (2008). The effect of ethnicity on facial anthropometry in Northern Iran. Singapore Medical Journal, (December), 4-8.

Jaruwan Klamklay, Yodpijitb, A. S. N., \& Pattersonc, P. E. (2008). Anthropometry of the southern Thai population. Journals \& Books International Journal of Industrial Ergonomics, 38(1). https://doi.org/https://doi.org/10.1016/j.ergo n.2007.09.001

Kroemer, \& Grandjean, E. (2005). Fitting the task to the human: a Textbook of Occupational Ergonomics (Fifth edit). London: Taylor and Francis Publisher.

Prabawati, R. (2012). Hubungan Beban Kerja Mental Dengan Stres Kerja Pada Perawat Bagian Rawat Inap Rika Prabawati.

S. Wignjosoebroto. (2003). Ergonomi, Studi Gerak dan Waktu Teknik Analisis untuk Peningkatan Produktivitas Kerja. Surabaya: Guna Widya.

Soetisna, H. R., Mahachandra, M., \& Widyanti, A. (2014). Data Antropometri Anak Sebagai Upaya Awal Penentuan Standar Ukuran Pakaian Anak ( Clothing Size ) Indonesia. Seminar Nasional Teknik Industri BKSTI, 103-108.

Sutalaksana, \& Iftikar, Z. (2006). Teknik Perancangan Sistem Kerja. Bandung: ITB.

Tan Kay Chuan, Hartono, M., \& Kumar, N. 
(2010). Anthropometry of the Singaporean and Indonesian populations. International Journal of Industrial Ergonomics, 40(4). https://doi.org/https://doi.org/10.1016/j.ergo n.2010.05.001

Tarwaka. (2015). Ergonomi Industri Dasar-Dasar Pengetahuan Ergonomi Dan Aplikasi di Tempat Kerja. Surakarta: Harapan Press.

Umami, M. K. (2017). Pengukuran Antropometri Untuk Desain Peralatan Yang Terkait Dengan Telinga: Sebuah Survei Pendahuluan. Seminar Nasional Teknologi Informasi Dan Kedirgantaraan (SENATIK), III.

https://doi.org/http://dx.doi.org/10.28989/se natik.v3i0.133

Yap, W. S., Chan, C. C., Chan, S. P., \& Wang, Y. T. (2001). Ethnic differences in anthropometry among adult Singaporean Chinese, Malays and Indians, and their effects on lung volumes. Respiratory Medicine, 95(4), 297-304. https://doi.org/10.1053/rmed.2001.1038

Yokota, M. (2005). Head and facial anthropometry of mixed-race US Army male soldiers for military design and sizing: A pilot study. Aplied Ergonomics, 36(3), 379-383. https://doi.org/https://doi.org/10.1016/j.aper go.2005.01.009 